\title{
Carboniferous Biostratigraphy, Northeastern Brooks Range,
}

Arctic Alaska

GEOLOGICA L S URVEY PROFESSIONAL PAPER 884 



\section{Carboniferous Biostratigraphy, Northeastern Brooks Range, Arctic Alaska}

By AUguSTuS K. ARMSTRONG, U.S. Geological Survey, and BERNARD L. MAMET, University of Montreal, Montreal, Canada

GEOLOG I CA L S UR REY PROAESSIOANAL PAPER 884

Eleven microfossil assemblage zones are recognized in two sections of Carboniferous rocks in the northeastern Brooks Range, correlated with six other previously described sections, and tied to the Cordilleran and Eurasian standards

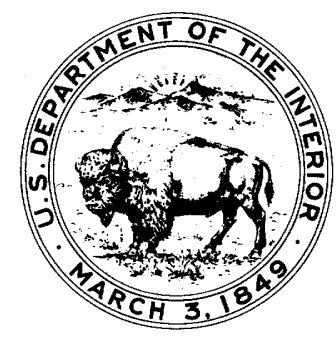




\title{
UNITED STATES DEPARTMENT OF THE INTERIOR \\ ROGERS C. B. MORTON, Secretary
}

\author{
GEOLOGICAL SURVEY
}

V. E. McKelvey, Director

Library of Congress Cataloging in Publication Data

Armstrong, Augustus K.

Carboniferous Biostratigraphy, northeastern Brooks Range, Arctic Alaska.

(Geological Survey Professional Paper 884)

Bibliography: p. 23-25.

Includes index.

Supt. of Docs. No.: I 19.16:884

1. Geology, Stratigraphic-Carboniferous. 2. Micropaleontology-Alaska-Brooks Range. 3. Stratigraphic correlationAlaska-Brooks Range. I. Mamet, Bernard L., joint author. II. Title. III. Series: United States. Geological Survey. Professional Paper 884. QE671.A7 $557.3^{\prime} 08 \mathrm{~s}\left[551.7^{\prime} 5\right]$ $75-619053$

For sale by the Superintendent of Documents, U.S. Government Printing Office Washington, D.C. 20402

Stock Number 024-001-02667-8 


\section{CONTENTS}

Abstract
Introduction
Acknowledgments
Stratigraphy
Endicott Group
Kekiktuk Conglomerate
Kayak(?) Shale
Lisburne Group
$\quad$ Wachsmuth and Alapah Limestones
$\quad$ Wahoo Limestone

\begin{tabular}{|c|c|}
\hline age & \\
\hline 1 & Kongakut River section \\
\hline 1 & Biostratigraphy \\
\hline 2 & Microfaunal assemblage zones \\
\hline 2 & Microfossil list \\
\hline 2 & Biota of the lagoonal facies, Alapał Limestone, Kongakut River \\
\hline 2 & $------1----$ \\
\hline 2 & Regional correlations \\
\hline 2 & Endicott Group \\
\hline 2 & Lisburne Group \\
\hline 4 & References cited \\
\hline 4 & ----1 \\
\hline
\end{tabular}

\section{ILLUSTRATIONS}

1. Index map of northern Alaska, and location of sections described in this report
2. Regional stratigraphic correlation chart of the Lisburne Group of arctic Alaska

3. Stratigraphic column of the Clarence River section 71A-1,2, northeastern brooks Range and explanation of lithologic and paleontologic symbols used in this report

4. Photomicrographs of carbonate rocks and microfossils; Clarence River section $71 \mathrm{~A}-1$, 2, and Kongakut River section $71 \mathrm{~A}-3$

5. Photograph of outcrops of Wahoo Limestone on the Clarence River

6. Photograph of Corwenia jagoensis Armstrong in the Atokan age beds of Wahoo Limestone

7. Stratigraphic column of the Kongakut River section $71 \mathrm{~A}-3,4,5,6$, northeastern Brooks Range

8. Photograph of the outcrop of the lower part of the Kongakut River section

9. Photomicrographs of carbonate rocks and microfossils, Kongakut River section $71 \mathrm{~A}-3$

10. Photomicrographs of carbonate rocks and microfossils, Kongakut River section $71 \mathrm{~A}-3,4$

11. Photomicrographs of carbonate rocks and microfossils, Kongakut River section $71 \mathrm{~A}-4,5$

12. Graphs showing the distribution of microfossils in lagoonal facies of Kongakut River section

13. Carboniferous biostratigraphic correlation chart, northeastern Brooks Range, Alaska _._.

14. Photograph of stromatolites in the Alapah Limestone from the Plunge Creek section 70A-4 22

15. Location map of Clarence River section $71 \mathrm{~A}-1,2$

16. Location map of Kongakut River section $71 \mathrm{~A}-3,4,5,6$ 



\title{
CARBONIFEROUS BIOSTRATIGRAPHY,
}

\section{NORTHEASTERN BROOKS RANGE, ARCTIC ALASKA}

\author{
By Augustus K. Armstrong ${ }^{1}$ and Bernard L. Mamet ${ }^{2}$
}

\begin{abstract}
Two sections of Carboniferous rocks were measured in the northeastern Brooks Range, arctic Alaska, and correlated with six other sections previously described. The section on the Clarence River is $739 \mathrm{~m}$ thick. Endicott Group sandstones and gray shales at the base of the section are $175 \mathrm{~m}$ thick and are Viséan (Meramecian) in age. They are overlain by $564 \mathrm{~m}$ of Lisburne Group carbonate rocks of Viséan (lower Chesterian) and Namurian-Westphalian (upper Chesterian, Morrowan, and Atokan) age. The base of the 1,062-mthick section on the Kongakut River is not exposed. The basal rocks of the Endicott Group are more than $341 \mathrm{~m}$ thick and are Viséan (Meramecian) in age. They are overlain by $721 \mathrm{~m}$ of Lisburne Group rocks of Viséan and Namurian (Meramecian and Chesterian) age. The Permian and Triassic Sadlerochit Formation unconformably overlies these Chesterian carbonate rocks.

Within these two sections, 11 microfossil assemblage zones are recognized. They are correlated with six other sections in the northeastern Brooks Range and tied to the Cordilleran and Eurasian standards.

The lower part of the Alapah Limestone in the Kongakut River section from 369 to $692 \mathrm{~m}$ represents shallow lagoonal sedimentation with a biota characterized by abundant calcispheres of the genera Calcisphaera, Parathurammina, and Vicinesphaera.

Lithologic studies reveal that the Lisburne Group carbonate rocks on the northeastern Brooks Range were deposited in shallow water on a slowly subsiding shelf. During brief and possibly cyclic periods carbonate sedimentation exceeded subsidence and formed regional and local intertidal to supratidal carbonate deposits.
\end{abstract}

\section{INTRODUCTION}

In 1971 Armstrong and J. T. Dutro, Jr., measured and sampled the Clarence River Section, and Armstrong,

\footnotetext{
${ }^{1}$ U.S. Geological Survey.

${ }^{2}$ University of Montreal, Montreal, Canada
}

H. N. Reiser, W. P. Brosgé, and R. L. Detterman measured and sampled the Kongakut River section. These sections are described in this report and are correlated with three stratigraphic sections previously described by Armstrong, Mamet, and Dutro (1970) and three sections described by Mamet and Armstrong (1972) from the northeastern Brooks Range. A foraminiferal zonation for the Lisburne Group in the central and eastern Brooks Range was established by Armstrong, Mamet, and Dutro (1970) and extended by them (1971) to the Lisburne Group of the Lisburne Hills and sea cliffs of northwestern Alaska.

A detailed systematic study and illustrations of the Carboniferous microfossils of the Lisburne Group are given by Mamet (in Armstrong and Mamet, 1975) with discussions of their stratigraphic and geographic ranges.

This report extends this microfossil zonation of the Lisburne Group to the Franklin and Romanzof Mountains of northeastern Alaska. The correlated sections project in an east-west direction along the north flank of the Brooks Range, from Clarence River near the Canadjan boundary west to the Sadlerochit Mountains, south of the Canning River to Marsh Fork, then finally east to the Romanzof Mountains in the northeastern Brooks Range with a line east to the Kongakut River (figs. 1,2). The carbonate rock classification used in this report is that of Dunham (1962).

A detailed historical review of stratigraphic studies of the Lisburne Group can be found in Bowsher and Dutro (1957) and Armstrong, Mamet, and Dutro (1970). 


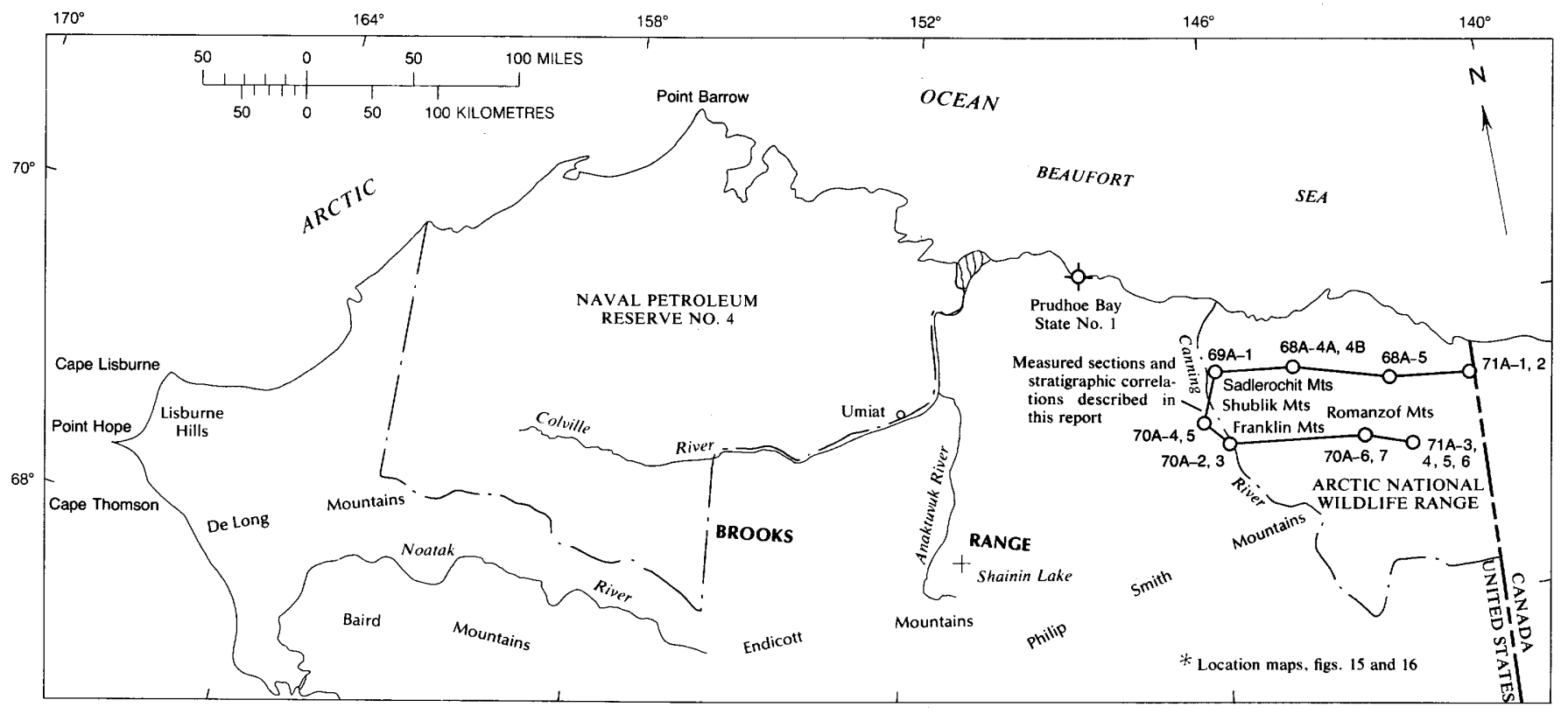

FIgURE 1.-Index map of northern Alaska, and location of sections described in this report.

\section{ACKNOWLEDGMENTS}

We thank the Naval Arctic Research Laboratory (Barrow), Office of Naval Research, for its logistical support of fieldwork in the summers of 1968, 1969, 1970, and 1971. We are grateful to our colleagues, J. Thomas Dutro, Jr., and William J. Sando, who helped in the preparation of the manuscript and provided critical review.

\section{STRATIGRAPHY}

\section{ENDICOTT GROUP}

Kekiktuk Conglomerate. - Brosgé, Dutro, Mangus, and Reiser (1962) named the basal sandstone beneath the Kayak(?) Shale in northeastern Alaska the Kekiktuk Conglomerate. The type section is on Whistler Creek, near the Neruokpuk Lakes. They found only indeterminate plant fragments within the formation and assigned it a Late(?) Devonian or Mississippian age, but they believed that it represents the basal conglomerate of the overlapping Mississippian sequence. Regionally, the Kekiktuk lies unconformably on strata ranging in age from Precambrian to Middle Devonian (Dutro and others, 1972). The base of the Kekiktuk Conglomerate is a pebble or cobble conglomerate grading upward to coarse-grained beach or near-shore deposits that in turn commonly grade upward into finer grained paralic sediments. The contact between the Kekiktuk Conglomerate and the overlying Kayak(?) Shale is generally gradational.

Kayak(?) Shale-Mississippian dark-gray to black shales lie beneath carbonate rocks of the Lisburne
Group throughout the eastern and central Brooks Range. Bowsher and Dutro $(1957$, p. 6) named these rocks the Kayak Shale, from the type locality on the south side of Mount Wachsmuth, east of Shainin Lake in the Endicott Mountains. The Kayak Shale at its type locality is Early Mississippian in age. Adjacent to and east of the Canning River, in the Arctic National Wildlife Range, a similar black shale occurs between the Kekiktuk Conglomerate and the Lisburne Group. Brosgé, Dutro, Mangus, and Reiser (1962, p. 2185) stated "this shale is at least in part of Late Mississippian age." They added, "Because of geologic structure, this shale can not be mapped continuously into the type Kayak. It might therefore be a discrete unit entirely younger than the Kayak and separated from the Kayak by a disconformity with the Mississippian rocks." Following Brosgé, Dutro, Mangus, and Reiser (1962), the shales in the area of this report are called Kayak (?) Shale.

\section{LISBURNE GROUP}

Wachsmuth and Alapah Limestones.-In the Shainin Lake area, Endicott Mountains, Bowsher and Dutro $(1957$, p. $3,4,6)$ recognized two new formations within the Lisburne Limestone and raised the Lisburne to group rank. The lower formation is the Wachsmuth Limestone, and the overlying one is the Alapah Limestone. Armstrong, Mamet, and Dutro's (1970, figs. $3,4)$ study indicates that on the basis of microfossils the age of the Wachsmuth at its type section is late Osagean (Zone 8) through Meramecian (Zone 12). They found that the Alapah Limestone contains microfaunas of 


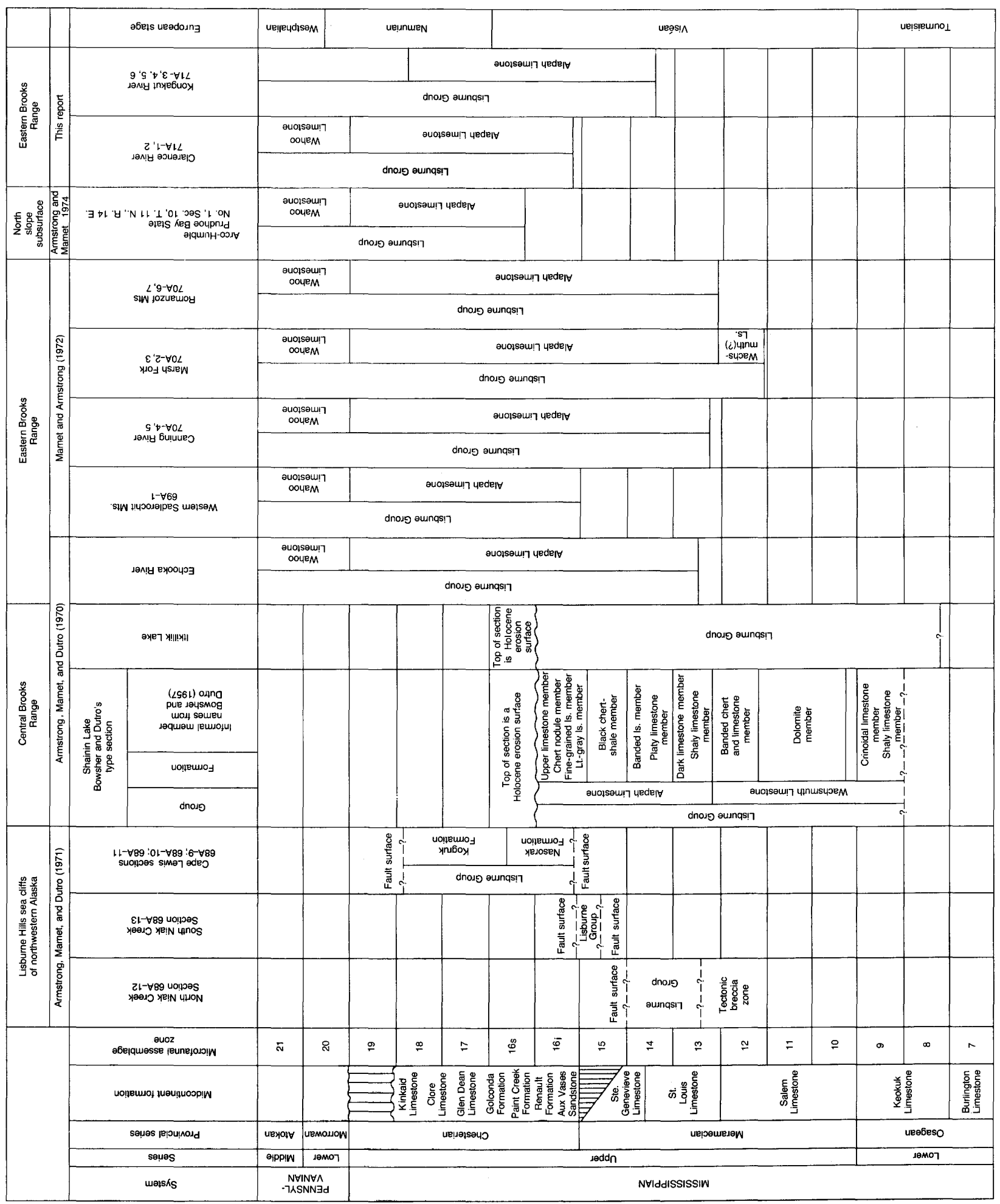


Meramecian (transition of Zones 12 and 13) through Chesterian (Zone 19) ages.

Wahoo Limestone.-Brosgé, Dutro, Mangus, and Reiser (1962, p. 2191-2192) described the type section of the Wahoo Limestone near Wahoo Lake as containing carbonate rocks of both Pennsylvanian(?) and Permian age. In the area of this report, the Wahoo Limestone as mapped by Reiser, Dutro, Brosgé, Armstrong, and Detterman (1970) may contain carbonate rocks of Late Mississippian (very latest Chesterian) and Early and Middle Pennsylvanian age (Morrowan and Atokan). The Pennsylvanian limestones overlie Mississippian carbonate rocks without a recognizable hiatus. The boundary between the two systems and the zones within them are based on microfaunal assemblages. The beds of Atokan age are unconformably overlain by Late Permian arenaceous limestones, sandstones, and conglomerates in the lowest part of the Sadlerochit Formation.

\section{CLARENCE RIVER SECTION}

At the outcrops of the Carboniferous rocks on the Clarence River (fig. 3) the oldest unit, the Kekiktuk Conglomerate, rests with a marked unconformity on arenaceous lower Paleozoic limestones (H. N. Reiser, oral commun., 1973). The basal $3 \mathrm{~m}$ of the Kekiktuk Conglomerate is gray to dark-gray sandstones, siltstones, and thin coal beds in 0.3- to 0.5-meter-thick beds.

Above this basal unit, the Kekiktuk Conglomerate is $97 \mathrm{~m}$ of dark-gray shales, arenaceous limestone nodules in dark-gray shale, and gray to pale-yellow-brown thin siltstones and sandstones with thin coal beds. Minor amounts of interbedded thin gray argillaceous limestones are present, and a foraminifer-crinoidal packstone occurs $37.8 \mathrm{~m}$ above the base (fig. $4 A$ ).

The contact of the Kekiktuk Conglomerate with the overlying Kayak(?) Shale is picked above the last thin coal bed at about the 100-m level. The Kayak(?) Shale consists of thin-bedded dark-gray shales, siltstones, and argillaceous fine-grained sandstones. Some thin-bedded siltstones and sandstones are reddish brown owing to hematitic cement. The contact of the Kayak(?) Shale with the Alapah Limestone is covered by a talus slope and is arbitrarily picked at about $175 \mathrm{~m}$ (fig. 3).

The carbonate rocks of the Lisburne Group in this section are commonly altered by tectonic stress, and affected horizons are shown in figure 3 .

The first good outcrop of the Alapah Limestone, found at $198 \mathrm{~m}$ above the base, is gray dolomite, formed by 5 to 10 -micrometre-size dolomite rhombs, with abundant and well-developed birdseye structures, small lithoclasts, stromatolites, and calcite pseudomorphs of gypsum (fig. $4 B$ ). The stromatolite zone is 15 to $17 \mathrm{~m}$ thick. The sedimentary structures clearly indicate a well-developed intertidal to supratidal facies.

Above the intertidal to supratidal facies, exposures are poor (fig. 3) until about $308 \mathrm{~m}$ above the base where typical Alapah crinoidal-bryozoan wackestones and packstones with nodular gray cherts are found. Detrital quartz sand is rare as is dolomite above the $250-\mathrm{m}$ level, except for 1- to 3-m-thick dolomite beds at the 371- and $396-\mathrm{m}$ level. The dolomite is formed by dolomite rhombs in the 20- to 30-micrometre size. The Alapah-Wahoo contact is put at the first occurrence of massive limestone and pale-yellowish-orange interbeds at $425 \mathrm{~m}$ above the base.

The Wahoo Limestone (fig. 5) is composed partly of tectonically stressed foraminifer-ooid grainstones (fig. $4 C$ ), coarse-grained foraminifer-ooid lump grainstones (fig. $4 D, E, F$ ), bryozoan-crinoid packstones and wackestones, lime mudstones and pale-yellowish-orangeweathering argillaceous thin-bedded dolomites. Detrital quartz, 50- to 100-micrometre size, is common in the dolomites. Large colonial corals are common in the upper part of the Wahoo Limestone (fig. 6).

The highest beds of the Wahoo Limestone are arenaceous packstone followed by $2 \mathrm{~m}$ of yellowishorange-weathering, arenaceous, bryozoan-crinoid wackestone. In the carbonate rocks the detrital quartz sand is $0.1-0.2 \mathrm{~mm}$ in size and rounded. The carbonate rocks of the Wahoo Limestone are inconformably overlain by Permian grayish-brown argillaceous calcareous siltstones and sandstones of the Sadlerochit Formation.

\section{KONGAKUT RIVER SECTION}

The Carboniferous section south of the Kongakut River (figs. 7, 8) is well exposed except that the lower part of the Kayak(?) Shale and older beds are cut out by a fault and covered by tundra.

The Kayak(?) Shale from the base to $134 \mathrm{~m}$ is dark-gray fissile shale with a few 3 - to 10 -cm-thick argillaceous beds and lenses of brown to gray siltstone and fine-grained sandstone. From 134 to $341 \mathrm{~m}$ the Kayak(?) Shale is an alternating series of dark-gray shales and dark-gray argillaceous spiculitic lime mudstones and wackestones (fig. $4 G, H .7,9 A$ ). A black, argillaceous lime mudstone with nodular to bedded chert is present from 192 to $223 \mathrm{~m}$. It is very siliceous and spiculitic and contains fragments of bryozoans and echinoderms. This unit is dolomitic in zones with abundant 50- to 100-micrometre-size dolomite rhombs. The contact of the the Kayak(?) Shale with the Alapah Limestone is gradational.

The lower part of the Alapah Limestone (fig. 7) from 342 to $571 \mathrm{~m}$ is an argillaceous, coralliferous, thinbedded foraminiferal-algal-bryozoan-echinoderm wackestone and packstone (figs. $9 B-H, 10 A-D$ ). From 


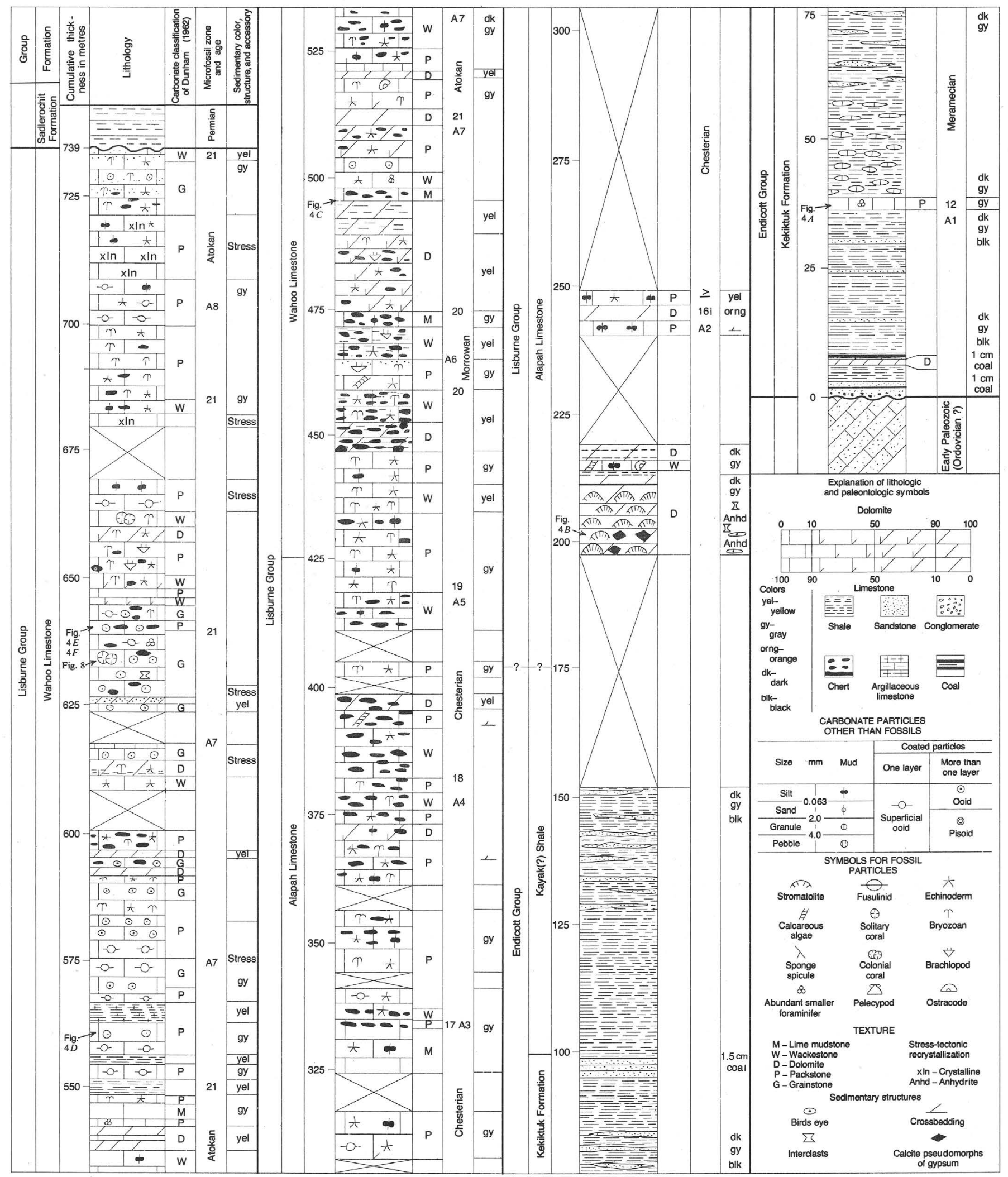

FIGURE 3.-Clarence River section, 71A-1, 2, northeastern Brooks Range, and explanation of lithologic and paleontologic symbols used in this report. 

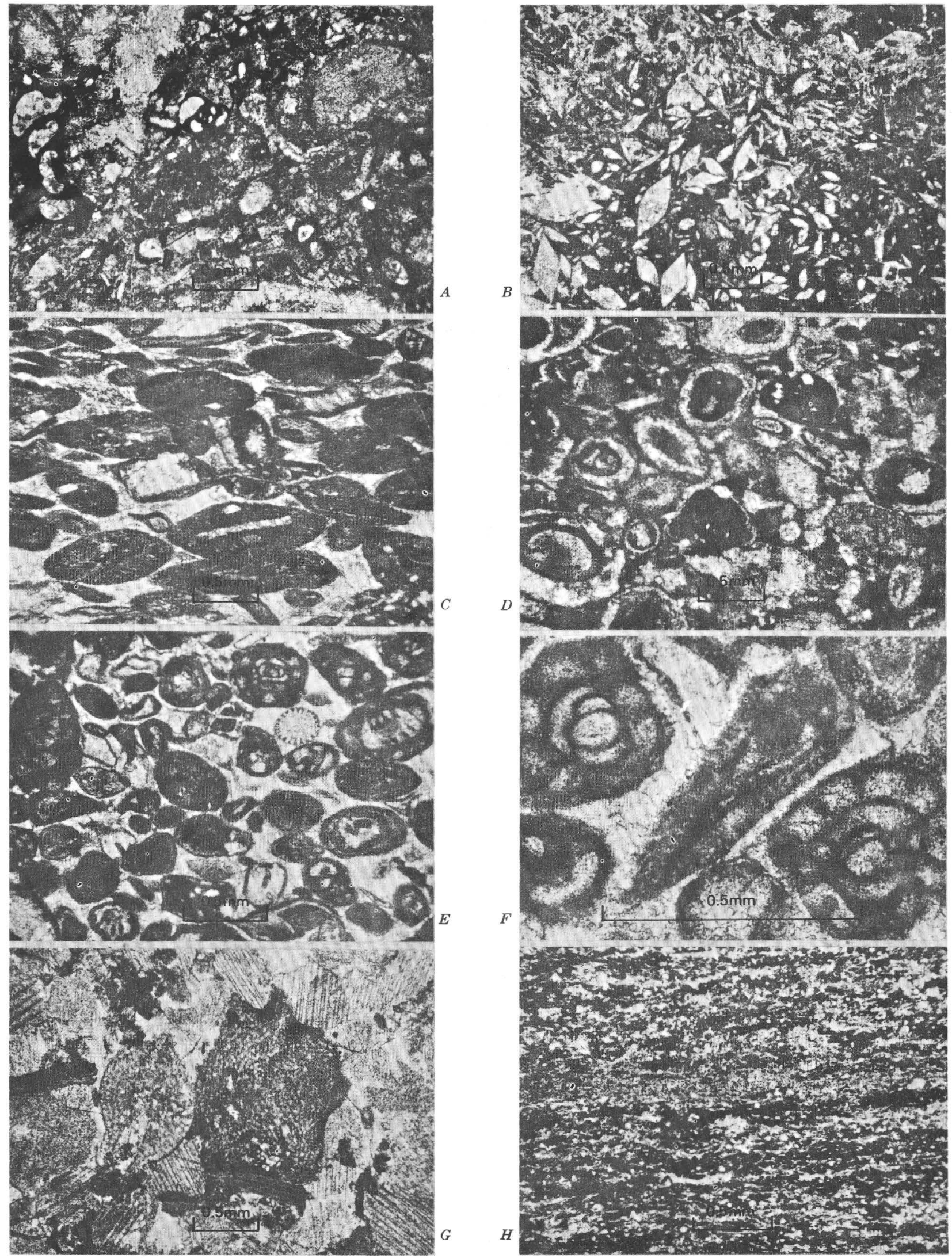

FIGURE 4.-Photomicrographs of carbonate rocks and microfossils, Clarence River section 71A-1, 2 and Kongakut River section 71A-3. Location shown in figures 3 and 7. 
571 to $576 \mathrm{~m}$ above the base superficial coated ooids and pelletoid packstones and abundant microfossils are present (figs. $10 E-F$ ). The Alapah Limestone above 600 $\mathrm{m}$ is much less argillaceous, light gray in color, and composed primarily of echinoderm-bryozoan-algaeforaminiferal-brachiopod wackestones and packstones. Lesser amounts of lime mudstones and dolomitic beds are present. Detrital quartz sand is very rare. Ooid beds are found at 685 and $775 \mathrm{~m}$, and grainstones and packstones composed of bryozoans and crinoids are not uncommon (figs. 7, 10C, G, $H, 11 A-F$ ). Above $900 \mathrm{~m}$ to $1,025 \mathrm{~m}$ the Alapah is a light-gray, massive bryozoanechinoderm packstone and grainstone, with minor amounts of wackestone and dolomites (fig. 11G, H). Above the 400-m level, dolomite is generally present in the form of 30- to 70-micrometre rhombs. The Alapah Limestone from $1,031.5$ to $1,062 \mathrm{~m}$ is arenaceous bryozoan-echinoderm wackstones, packstones, grainstones, and cherty dolomites. The dolomite is formed by 30 - to 50 -micrometre size dolomite rhombs.

Figure 4.- Bar scale $=0.5 \mathrm{~mm} . A-F$, Clarence River section. $A$, Recrystallized crinoid-foraminifer packstone. Pressure solution is widespread and foraminifer tests are partially dissolved; Eoforschia sp., Endothyra sp., and Earlandia of the group $E$. clavatula (Howchin) are present. Univ. Montréal 271/6, section $71 \mathrm{~A}-2+124 \mathrm{ft} ; 37.8 \mathrm{~m}$ above the base, Kayak Shale(?) (lateral equivalent of the Wachsmuth Limestone), Zone 12 (or slightly younger?), upper Salem age equivalent, middle Viséan. $B$, Calcite pseudomorphs of gypsum in a fine-grained microdolomite, former pelletoidal wackestone. Univ. Montréal 271/11, section 71A$2+660 \mathrm{ft} ; 201.2 \mathrm{~m}$ above the base, Alapah(?) Limestone, zone undetermined (Zone 15 or 16?), upper Meramec or lower Chester age equivalent, late Viséan. $C$, Tectonically stressed foraminiferooid grainstone. Univ. Montréal 271/2, section 71A-2+1,600 ft; $487.7 \mathrm{~m}$ above the base, Wahoo Limestone, Zone 20, Morrow age equivalent, late Namurian. $D$, Early cemented lump grainstone. Neoarchaediscus incertus (Grozdilova and Lebedeva) and algal fragments are present. Univ. Montréal 270/37, section 71A-1+590 $\mathrm{ft} ; 560.8 \mathrm{~m}$ above the base, Wahoo Limestone, Zone 21, Atoka age equivalent, early Westphalian. $E$, A typical coarse-grained foraminifer-ooid lump grainstone of the middle part of the Wahoo Limestone. Pseudostaffella sp., Eoschubertella sp., Globivalvulina sp., and Endothyra sp. are partly coated and mud filled. Echinoid spines, pelmatozoan plates, and algae are present. Univ. Montréal $270 / 27$, section $71 \mathrm{~A}-1+345 \mathrm{ft} ; 635.5 \mathrm{~m}$ above the base of the section, Zone 21, Atoka age equivalent, early Westphalian. $F$, Detail of $E$ showing two sections of Eoschubertella yukonensis (Ross). Univ. Montréal 270/32, as fig. $4 E, G, H$, Kongakut River section. $G$, Two sections of Stacheia skimoensis Mamet and Rudloff in a crinoidbryozoan packstone. Note the excellent preservation of the thalli, in spite of the widespread and extensive epitaxial overgrowth. Univ. Montréal 274/30, section $71 \mathrm{~A}-3+565 \mathrm{ft} ; 172.2 \mathrm{~m}$ above the base, Kayak Shale(?) interfingering with Wachsmuth Limestone, Zone 12, upper Salem age equivalent, middle Viséan. $H$, Chertified, layered radiolarite. Univ. Montréal 274/36, section $71 \mathrm{~A}-3+695 \mathrm{ft}$; $211.8 \mathrm{~m}$ above the base, Kayak Shale(?), zone undetermined (Zone 13 or 14?), upper Meramec age equivalent, middle to late Viséan.

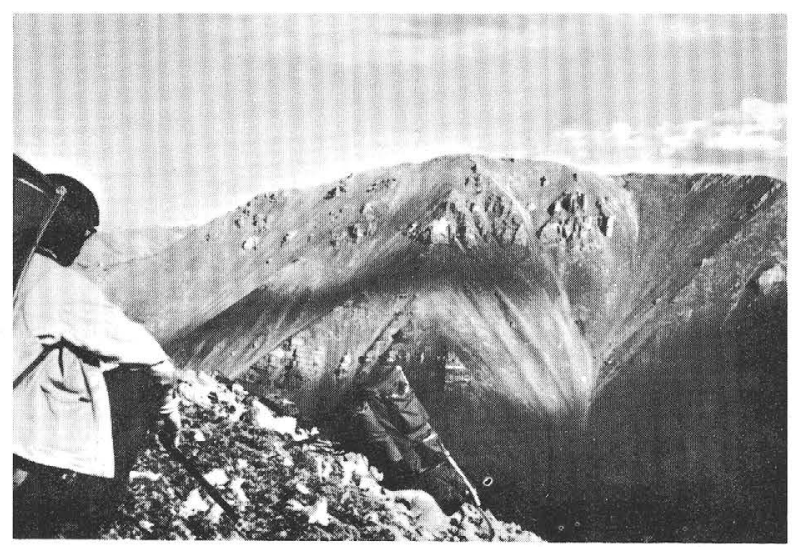

Figure 5.-Outcrops of Wahoo Limestone on the Clarence River. View east.

The Permian and Triassic Sadlerochit Formation unconformably overlies bryozoan-crinoid wackestones of the Alapah Limestone.

\section{BIOSTRATIGRAPHY}

\section{MICROFAUNAL ASSEMBLAGE ZONES}

The microfaunal assemblage zones used in this study have been used by Mamet and Gabrielse (1969), Mamet and Mason (1968), and Mamet (1968) to correlate the Carboniferous of western Canada with the Carboniferous of the northern Cordillera of the United States (Sando and others, 1969). Armstrong, Mamet, and Dutro $(1970,1971)$ and Mamet and Armstrong (1972) also used these zones to correlate the Lisburne Group of the eastern and central Brooks Range and the Lisburne Hills region of northwestern Alaska. Detailed systematic descriptions, stratigraphic and geographic distributions, and illustrations of the microfossils of this report

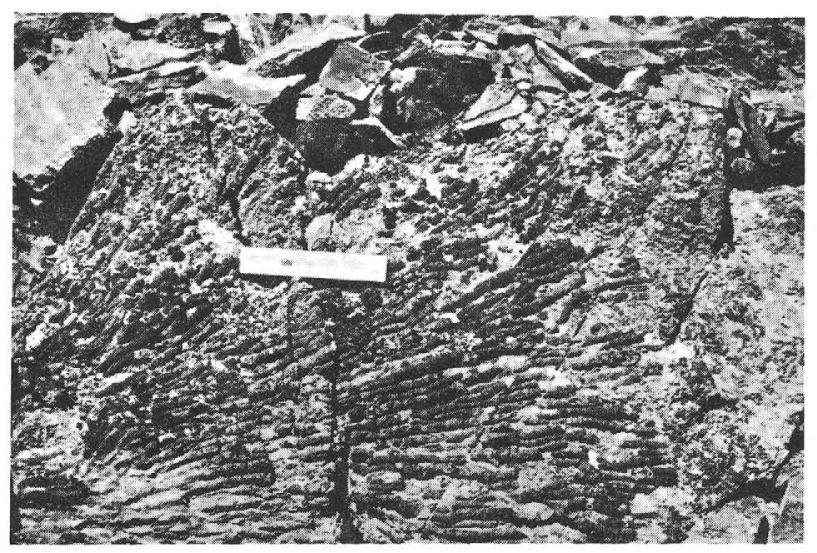

Figure 6.-Corwenia jagoensis Armstrong in the Atokan age beds of Wahoo Limestone, $635 \mathrm{~m}$ above the base of the Clarence River section 71A-1, 2. The exterior of the corallum is partly silicified. The scale is $15 \mathrm{~cm}$ long. 


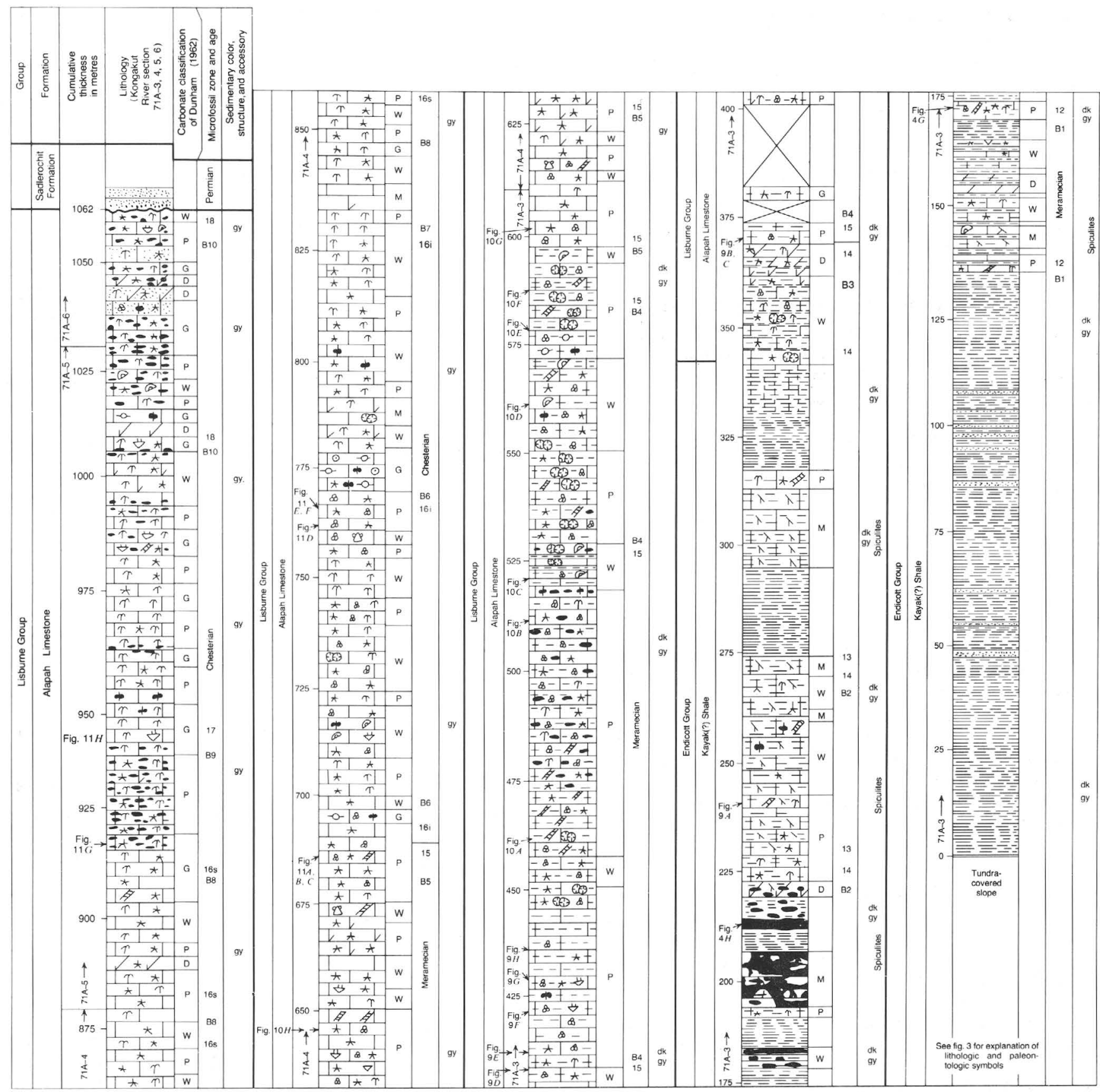

FIGURE 7.- Kongakut River section, 71A-3, 4, 5, 6, northeastern Brooks Range, arctic Alaska.

are given by Mamet (in Armstrong and Mamet, 1975). Microfossil lists for the eastern Sadlerochit Mountains section $68 \mathrm{~A}-4 \mathrm{~A}, 4 \mathrm{~B}$ and the Egaksrak River section 68A-5 can be found in Armstrong, Mamet, and Dutro (1970), and for the western Sadlerochit Mountains section $69 \mathrm{~A}-1$, Plunge Creek section $70 \mathrm{~A}-4$, 5, Marsh Fork section 70A-2, 3, and the Syncline section 70A-6, 7 in Mamet and Armstrong (1972).

The Clarence River section 71A-1, 2 and Kongakut River section $71 \mathrm{~A}-3,4,5,6$ are new, and the microfossil lists are given below.

The microfacies of Alaska, as in most of the Taimyr-Alaska foraminiferal realm (Mamet, 1962, Mamet and Belford, 1968; Mamet and Skipp, 1970), are generally poor in foraminifers and algae. Within the sections of the Lisburne Group of northeastern Alaska studied in this report, 11 foraminiferal assemblages can be recognized and correlated with the Cordilleran and Eurasian Carboniferous zonations (Sando and others, 1969). 


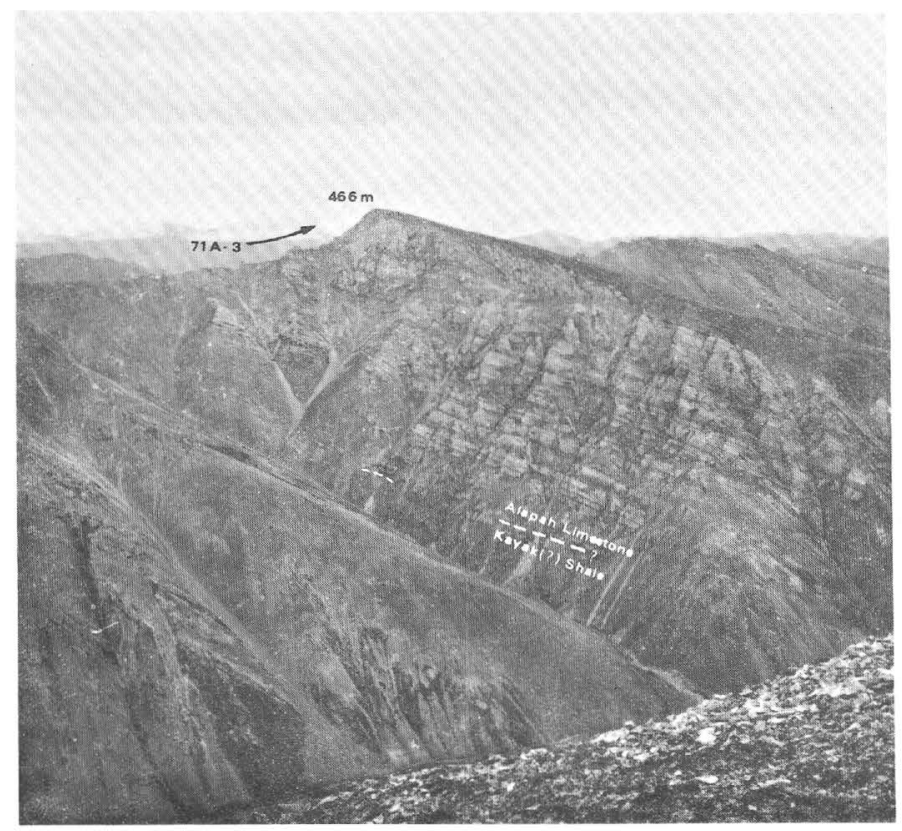

Figure 8.-Outcrop of the lower part of the Kongakut River section, showing the well-exposed upper part of the Kayak(?) Shale and the lower part of the Alapah Limestone. View east.

Wood and Armstrong (1975) give a detailed analysis of the petrography and diagenesis of the Lisburne Group carbonate rocks in sections $69 \mathrm{~A}-1$ and $68 \mathrm{~A}-4 \mathrm{~A}, \mathrm{~B}$ for the Sadlerochit Mountains and the Plunge Creek section $70 \mathrm{~A}-4,5$.

\section{Microfossil list \\ Clarence River section}

A-1 (120-140 ft); 36.6-42.7 m

Calcisphaera laevis Williamson

Calcisphaera pachysphaerica (Pronina)

Dainella sp.

Dainella anivikensis Mamet in Armstrong and Mamet

Earlandia of the group E. clavatula (Howchin)

Earlandia vulgaris (Rauzer-Chernoussova and Reitlinger)

Endothyra sp.

Endothyra of the group E. bowmani Phillips in Brownemend Brady

Endothyra of the group E. similis Rauzer-Chernoussova and Reitlinger

Eoendothyranopsis sp.

Eoendothyranopsis of the group E. spiroides (Zeller)

Eoforschia sp.

Globoendothyra sp.

Globoendothyra of the group G. baileyi (Hall)

Globoendothyra of the group G. tomiliensis (Grozdilova in Lebedeva)

Stacheia $\mathrm{sp}$

Stacheia skimoensis Mamet and Rudloff

Stacheoides sp.

Age: Zone 12 or slightly younger, middle Viséan, upper Salem age equivalent.

A-2 (790 ft); $240.8 \mathrm{~m}$

Calcisphaera sp.

cf. Neoarchaediscus sp.
Age: Zone 16i or younger, late Viséan, lower Chester age equivalent or younger.

A-3 (1,010-1,205 ft); 307.8-367.3 m

Archaediscus sp.

Archaediscus of the group A. krestovnikovi RauzerChernoussova

Archaediscus krestovnikovi Rauzer-Chernoussova

Asteroarchaediscus sp.

Asteroarchaediscus baschkiricus (Krestovnikov and Teodorovitch

Calcisphaera laevis Williamson

Calcisphaera pachysphaerica (Pronina)

Earlandia sp.

Earlandia clavatula (Howchin)

Earlandia of the group $E$. vulgaris (Rauzer-Chernoussova and Reitlinger)

Endothyra sp.

Endothyra of the group E. bowmani Phillips in Brown emend Brady

Globoendothyra sp.

Neoarchaediscus sp.

Planospirodiscus $\mathrm{sp}$.

Priscella sp.

Priscella of the group P. prisca (Rauzer-Chernoussova and Reitlinger)

Stacheia sp.

Stacheoides sp.

Tetrataxis sp.

Zellerina sp.

Age: Zone 17, early Namurian, middle Chester age equivalent.

A-4 (1,230-1,250 ft); 374.9-381 m

Archaediscus sp.

Archaediscus of the group A. krestovnikovi RauzerChernoussova

Asteroarchaediscus sp.

Biseriella sp.

Calcisphaera $\mathrm{sp.}$

Earlandia sp.

Endothyra sp.

Globoendothyra sp.

Neoarchaediscus sp.

Planospirodiscus sp.

Priscella sp.

Zellerina sp.

Age: Zone 18, early Namurian, upper Chester age equivalent

A-5 (1,380-1,400 ft); 420.6-426.7 m

Archaediscus sp.

Archaediscus of the group A. krestovnikovi RauzerChernoussova

Asteroarchaediscus sp.

Asteroarchaediscus of the group A. baschkiricus (Krestovnikov and Teodorovitch)

Calcisphaera sp.

Calcisphaera pachysphaerica (Pronina)

Earlandia sp.

Endothyra sp.

Neoarchaediscus sp.

Planospirodiscus sp.

Priscella sp.

Priscella of the group P. prisca (Rauzer-Chernoussova and Reitlinger)

Pseudoammodiscus sp.

Quasiarchaediscus sp. 


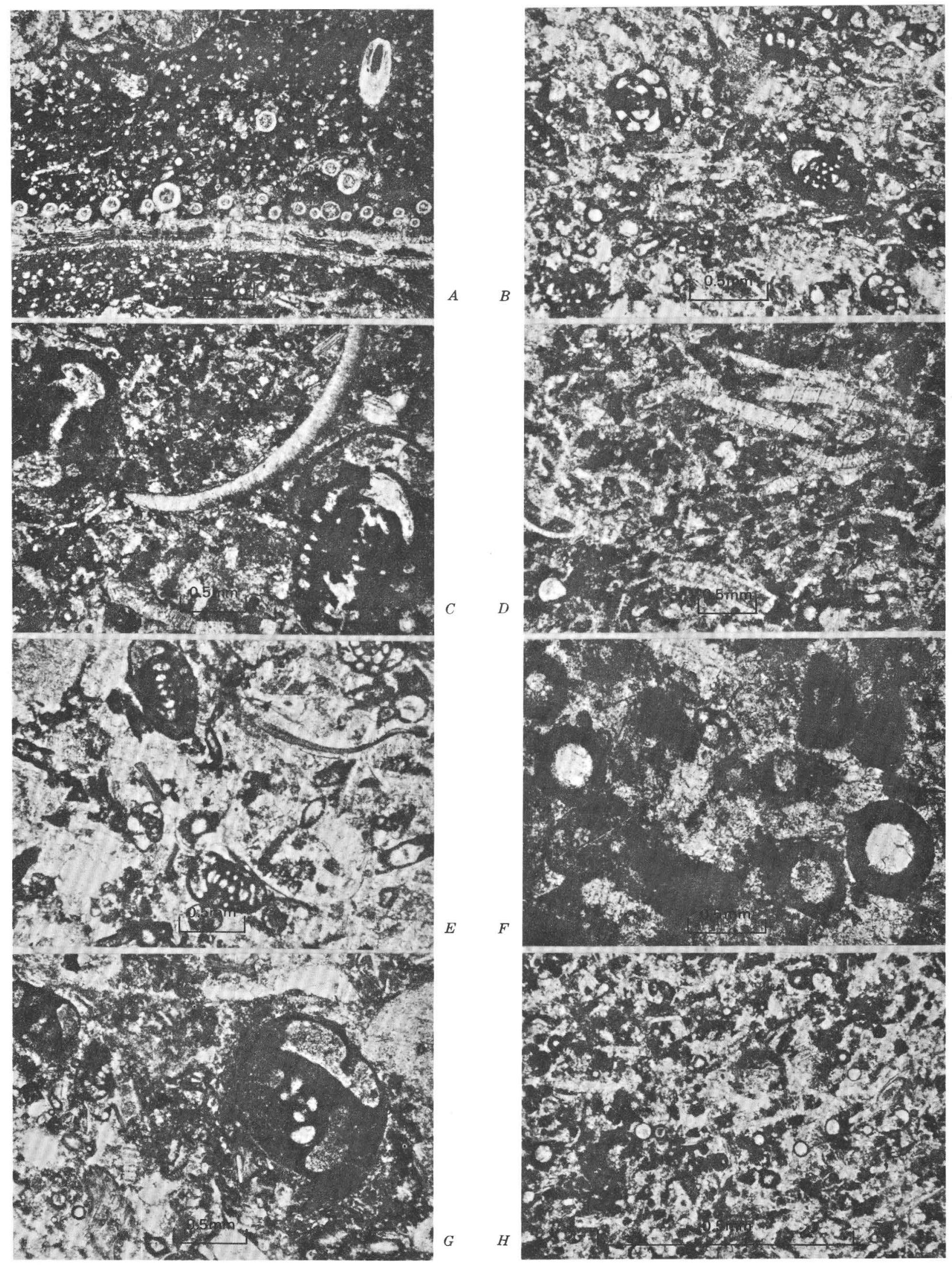

FIGURE 9.- Photomicrographs of carbonate rocks and microfossils, Kongakut River section 71A-3. Location shown in figure 7. 
Quasiarchaediscus rugosus Brazhnikova

Zellerina sp.

Age: Zone 19, middle Namurian, uppermost Chester age equivalent.

A-6 (1,410-1,550 ft); 429.8-472.4 m

Archaediscus sp.

Asphaltina cordillerensis Mamet

Asteroarchaediscus sp.

Asteroarchaediscus of the group A. baschkiricus (Krestovnikov and Teodorovitch)

Biseriella sp.

Biseriella of the group B. parva (Chernysheva)

Calcisphaera sp.

Earlandia sp.

Eostaffella sp.

Globivalvulina sp.

Millerella sp.

Neoarchaediscus sp.

Planoendothyra aljutovica (Reitlinger)

FIGURE 9.-Bar scale $=0.5 \mathrm{~mm} . A-H$, Kongakut River section. $A, \mathrm{~A}$ partially silicified brachiopod shell in a dark mudstone. The spines have been preferentially silicified. Univ. Montréal 275/5, section $71 \mathrm{~A}-3+790 \mathrm{ft} ; 240.8 \mathrm{~m}$ above the base, Kayak(?) Shale, Zone 14, St. Louis age equivalent, early late Viséan. $B$, Recrystallized foraminiferal-algal packstone. Calcispheres (Calcisphaera sp., Parathurammina, sp., Vicinesphaera sp.) and Foraminifera [Globoendothyra sp., Eoendothyranopsis sp., Earlandia of the group $E$. clavatula (Howchin), cf. Skippella? sp., and Endothyra sp.] are abundant. Univ. Montréal 275/7, section 71A-3+1,210 ft; $368.8 \mathrm{~m}$ above the base, Alapah Limestone, Zone 15, Ste. Genevieve age equivalent, middle late Viséan. $C$, Detail of 9B. Axial sections of two gigantic Eoendothyranopsis? robustus (McKay and Green) in a slightly recrystallized packstone. Note the feeble pseudochomata. Univ. Montréal 275/10, section 71A-3+1,210 ft; $368.8 \mathrm{~m}$ above the base, Alapah Limestone, Zone 15, Ste. Genevieve age equivalent, middle late Viséan. D, Recrystallized algal-pelletoidal packstone. Pseudoissinella alaskaensis Mamet and Rudloff and Kamaena sp. are intertwined and probably formed a continuous mesh throughout the sediment. Calcispheres are widespread. Univ. Montréal 275/28, section $71 \mathrm{~A}-3+1,340 \mathrm{ft} ; 408.4 \mathrm{~m}$ above the base, Alapah Limestone, Zone 15, Ste. Genevieve age equivalent, middle late Viséan. $E$, Medium-grained, poorly sorted crinoid-foraminifer-brachiopod grainstone. Eoendothyranopsis of the group E. ermakiensis (Lebedeva), Endothyra sp., Earlandia sp., Earlandinella sp., and Planoendothyra sp. are conspicuous. Univ. Montréal 275/30, section $71 \mathrm{~A}-3+1,350 \mathrm{ft} ; 411.5 \mathrm{~m}$ above the base, Alapah Limestone, Zone 15 , Ste. Genevieve age equivalent, middle late Viséan. $F$, Detail of a pelletoidal-Calcisphaera packstone. Two Calcisphaera pachysphaerica (Pronina)are present. Though foraminifers present in this facies are mud filled, the interior of the calcispheres is usually a clear clean cement. Univ. Montréal 275/40, section 71A-3+1,380 ft; $420.6 \mathrm{~m}$ above the base, Alapah Limestone, Zone 15, Ste. Genevieve age equivalent, middle late Viséan. $G$, Recrystallized, poorly sorted crinoid-bryozoan-brachiopod-foraminifer packstone with a gigantic Globoendothyra of the group G. globulus d'Eichwald (note the characteristic continuous differentiated wall structure [clear layer]). Univ. Montréal 276/1, section 71A-3+1,400 ft; $426.7 \mathrm{~m}$ above the base, Alapah Limestone, Zone 15, Ste. Genevieve age equivalent, middle late Viséan. $H$, Calcisphere-pelletoidal-algal grainstone. The "rectangular" clear calcite ghosts are recrystallized thalli of Pseudoissinella and of kamaenid algae. Univ. Montréal $276 / 2$, section $71 \mathrm{~A}-3+1,430 \mathrm{ft} ; 435.9 \mathrm{~m}$ above the base, Alapah Limestone, Zone 15, Ste. Genevieve age equivalent, middle late Viséan.
Planospirodiscus sp.

Stacheoides sp.

Stacheeinae

Zellerina sp.

Age: Zone 20, late Namurian, Morrow age equivalent.

A-7 (1,700-2,100 ft); $518.1-640.1 \mathrm{~m}$

Asphaltina sp.

Asphaltina cordillerensis Mamet

Asteroarchaediscus sp.

Asteroarchaediscus baschkiricus (Krestovnikov and Teodorovitch)

cf. Biseriella? sp.

Calcisphaera sp.

Climacammina sp.

Earlandia sp.

Eoschubertella sp. Very abundant

Eoschubertella yukonensis (Ross)

Globivalvulina sp.

Globivaluulina of the group G. bulloides (Brady)

cf. Millerella sp.

Neoarchaediscus incertus (Grozdilova and Lebedeva)

Palaeotextularia sp.

Planoendothyra sp.

Planospirodiscus sp.

Planospirodiscus taimyricus Sossipatrova

Pseudocornuspira sp.

Pseudoendothyra sp. Very abundant

Pseudoendothyra britishensis Ross

Pseudoglomospira sp.

Pseudostaffella sp. Abundant

Stacheoides sp.

Tetrataxis sp.

Tuberitina sp.

Zellerina sp.

Age: Zone 21, Westphalian, Atoka age equivalent (very abundant fusulinid fauna).

A-8 (2,240-2,390 ft); 682.8-728.5 m

Asphaltina sp.

Asteroarchaediscus sp.

Asteroarchaediscus baschkiricus (Krestovnikov and Teodorovitch)

Calcisphaera sp.

Endothyra sp.

Earlandia sp.

Eoschubertella sp. Very scarce

Globivalvulina sp.

Globivalvulina of the group G. bulloides (Brady)

Neoarchaediscus sp.

Neoarchaediscus incertus (Grozdilova and Lebedeva)

Planospirodiscus sp.

Planospirodiscus minimus (Grozdilova and Lebedeva)

Planospirodiscus taimyricus Sossipatrova

Pseudoendothyra sp.

Tetrataxis sp.

Tuberitina sp.

Zellerina sp.

Age: Zone 21, Westphalian, Atoka age equivalent (very scarce fusulinid fauna).

\section{Kongakut River section}

B-1 (440-595 ft); 134.1-181.4 m

Calcisphaera sp.

Earlandia of the group E. vulgaris (Rauzer-Chernoussova and Reitlinger) 

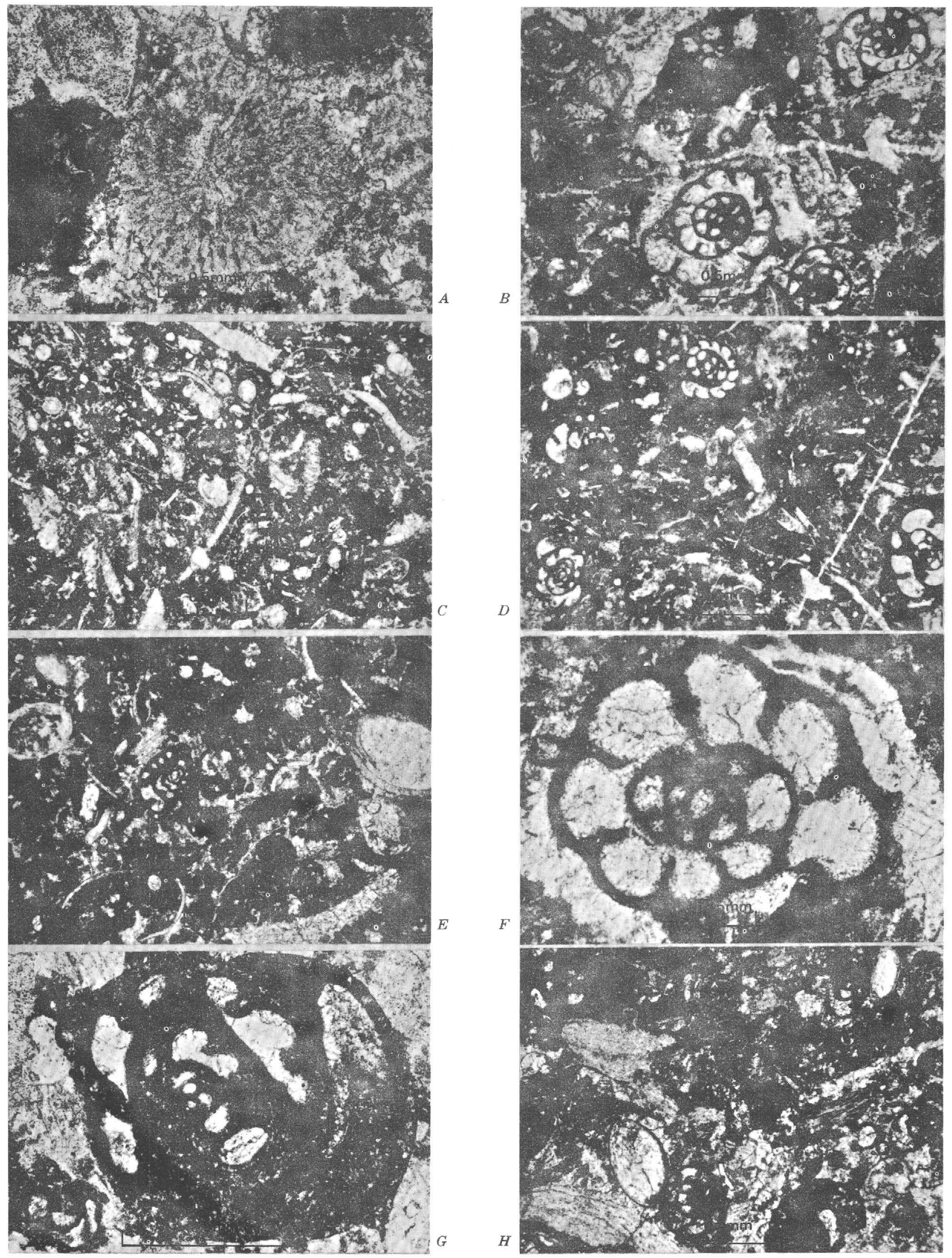

FIGURE 10.- Photomicrographs of carbonate rocks and micro fossils, Kongakut River section 71A-3, 4. Locations shown in figure 7 . 
Endethyra sp.

Endethyranella sp.

Ciloboendothyra sp.

Globoendothyra of the group (G. bailevi (Hall)

(iloboendothyra paula (Vissarionova)

Priscella sp.

Pséudoammodiscus sp.

Stacheia sp.

Stacheia skimoensis Mamet and Rudloff

Stacheoides sp.

Age: Zone 12, early middle Viséan, upper Salem age equivalent.

B-2 (730-865 ft): $222.5-263.7 \mathrm{~m}$

Brunsia sp.

Brunsia lenensis Bogush and Yuferev

Calcisphaera sp.

Endothyra sp.

Endothyra of the group E. bowmani Phillips in Brown emend Brady

Globoendothyra sp.

Planoarchaediscus sp.

Priscella sp.

Pseudoammodiscus sp.

Stacheoides sp.

Figure 10.- Bar scale $=0.5 \mathrm{~mm} . A-H$, Kongakut River section. $A$, A partially mud-filled Globoendothyra of the group G. globulus d'Eichwald showing the differentiated wall structure (clear layer). Univ. Montréal 276/3, section 71A-3+1,515 ft; $461.8 \mathrm{~m}$ above the base, Alapah Limestone, Zone 15, Ste. Genevieve age equivalent, middle late Viséan. $B$, Poorly sorted, recrystallized foraminiferbrachiopod-crinoid packstone. Foraminifers are Eoendothyranopsis? robustus (McKay and Green), Globoendothyra paula (Vissarionova), and Endothyranopsis sp. Ostracodes, pelecypods calcispheres, and pellets are also present. Univ. Montréal 276/32, section $71 \mathrm{~A}-3+1,680 \mathrm{ft} ; 512.1 \mathrm{~m}$ above the base, Alapah Limestone, Zone 15, Ste. Genevieve age equivalent, middle late Visean. $C$, Eoendothyranopsis cf. E. thompsoni (Anisgard and Campau) in a pelletoidal wackestone. Mud and lumps have a tendency to form aggregates. Calcispheres (Calcisphaera sp., Parathurammina sp.), pelecypods ostracodes, brachiopods, and algae are also present. Univ. Montréal 276/34, section 71A-3+1,710 ft; $521.2 \mathrm{~m}$ above the base, Alapah Limestone, Zone 15, Ste. Genevieve age equivalent, middle late Viséan. D, Endothyranopsis compressus (RauzerChernoussova and Reitlinger). Univ. Montréal 277/15, section $71 \mathrm{~A}-3+1,840 \mathrm{ft} ; 560.8 \mathrm{~m}$ above the base, Alapah Limestone, Zone 15 , Ste. Genevieve age equivalent, middle late Viséan. $E$, Recrystallized algal-pelletoidal packstone. Intertwined filaments of Pseudoissinella sp. associated with pelecypods. Calcisphaera sp., Vicinisphaera sp. and crushed endothyrids are present. Univ. Montréal 277/16, section 71A-3+1,895 ft; $577.6 \mathrm{~m}$ above the base, Alapah Limestone, Zone 15, Ste. Genevieve age equivalent, middle late Viséan. $F$, Same facies as the preceding figure with abundant endothyrids, globoendothyrids, and endothyranopsids. Univ. Montréal $227 / 21$, section $71 \mathrm{~A}-3+1,925 \mathrm{ft}$; $586.7 \mathrm{~m}$ above the base, Alapah Limestone, Zone 15, Ste. Genevieve age equivalent, middle late Viséan. G, A unique record of the algae Ungdarella in the late Viséan. Univ. Montréal 277/25,section 71A-3+1,970 ft; $600.5 \mathrm{~m}$ above the base, $63 \mathrm{X}$, Alapah Limestone, Zone 15, Ste. Genevieve age equivalent, middle late Viséan. $H$, Medium-grained, poorly sorted, foraminifer-lump grainstone. Eoendothyranopsis macrus (Zeller) is particularly abundant. Univ. Montréal 227/29, section $71 \mathrm{~A}-4+120 \mathrm{ft} ; 646.2 \mathrm{~m}$ above the base, $25 \mathrm{X}$, Alapah Limestone, Zone 15, Ste. Genevieve age equivalent, middle late Viséan.
Age: "Brunsia facies," probably Zone 14?, early late(?)

Viséan, St. Louis age equivalent.

B-3 $(1,170-1,190 \mathrm{ft}) ; 356.6-362.7 \mathrm{~m}$

Brunsia sp.

Brunsia lenensis Bogush and Yuferev

Calcisphaera sp.

Diplosphaerina $\mathrm{sp}$.

Earlandia sp.

Endothyra $\mathrm{sp}$.

Endothyra of the group E. bowmani Phillips in Brown emend Brady

Endothyra of the group E. similis Rauzer-Chernoussova and Reitlinger

Eoendothyranopsis sp.

Eoendothyranopsis of the group E. pressus (Grozdilova in Lebedeva)

Eoendothyranopsis of the group E. ermakiensis (Lebedeva)

Eoendothyranopsis scitulus Toomey

Globoendothyra paula (Vissarionova)

Priscella sp.

Pseudoammodiscus sp.

Stacheia sp.

Age: Zone 14, early late Viséan, St. Louis age equivalent.

B-4 (1,210-1,900 ft); 368.8-579.1 m

Archaediscus sp.

Archaediscus of the group A. krestovnikovi RauzerChernoussova

Archaediscus of the group A. moelleri Rauzer-Chernoussova ef. Banffella? sp.

Brunsia sp.

Calcisphaera laevis Williamson

Calcisphaera pachysphaerica (Pronina)

Diplosphaerina sp.

Earlandia of the group E. clavatula (Howchin)

Earlandia of the group E. vulgaris (Rauzer-Chernoussova and Reitlinger)

Earlandinella sp.

Endothyra sp.

Endothyra of the group E. bowmani Phillips in Brown emend Brady

Endothyra of the group E. similis Rauzer-Chernoussova and Reitlinger

Eoendothyranopsis of the group E. ermakiensis (Lebedeva)

Eoendothyranopsis cf. E. utahensis (Zeller)

Eoendothyranopsis? robustus (McKay and Green)

Eoendothyranopsis cf. E. thompsoni (Anisgard and Campau)

Eoforschia sp.

Epistacheoides sp.

Eotuberitina sp.

Globoendothyra of the group G. globulus d'Eichwald

Globoendothyra paula (Vissarionova)

Issinella? sp.

Kamaena sp.

Kamaena index (von Möller) Scarce

Kamaena lahuseni (von Möller) Scarce

Koninckopora sp. Very scarce

Koninckopora inflata (de Koninck) One specimen

Palaeocancellus sp.

Parathurammina sp.

Parathurammina of the group $P$. cushmani Suleimanov

Parathurammina of the group $P$. suleimanovi Lipina

Planoendothyra sp.

Priscella sp.

Priscella devexa Rauzer-Chernoussova

Priscella prisca (Rauzer-Chernoussova and Reitlinger) 

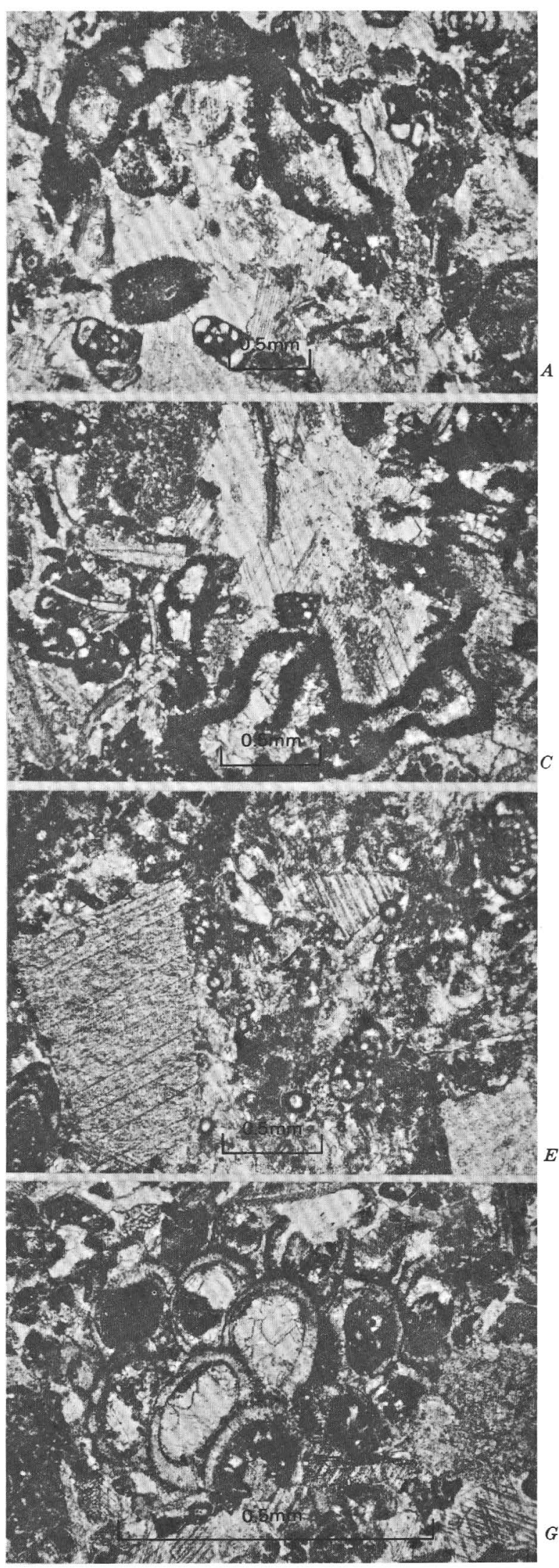
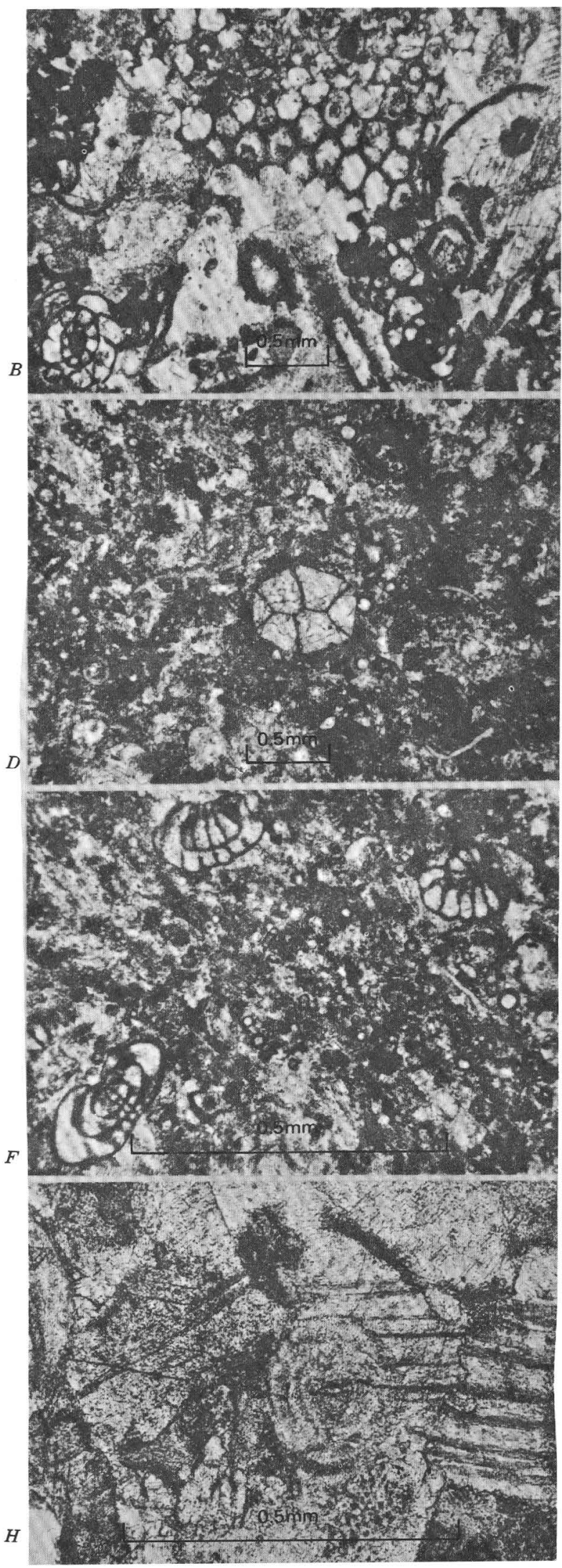

FigURE 11.- Photomicrographs of carbonate rocks and microfossils, Kongakut River section 71A-4, 5. Location shown in figure 7. 
Pseudoammodiscus sp.

Pseudoissinella sp.

Pseudoissinella alaskaensis Mamet and Rudloff

Radiosphaerina sp.

Skippella? sp.

Stacheoides sp.

Tetrataxis sp.

Vicinesphaera sp.

Yukonella sp. Very scarce

Age: Zone 15, middle late Viséan, Ste. Genevieve age equivalent.

B-5 (1,960-2,260 ft); 597.4-688.8 m

Archaediscus sp.

Brunsia sp.

Calcisphaera laevis Williamson

Calcisphaera pachysphaerica (Pronina)

Earlandia sp.

Earlandia of the group E. clavatula (Howchin)

Earlandia of the group E. vulgaris (Rauzer-Chernoussova and Reitlinger)

Endothyra sp.

Endothyra of the group E. bowmani Phillips in Brown emend Brady

Endothyra of the group E. similis Rauzer-Chernoussova and Reitlinger

Endothyranopsis sp.

Endothyranopsis compressus (Rauzer-Chernoussova and Reitlinger)

Figure 11.-Bar scale $=0.5 \mathrm{~mm}$. Kongakut River section. $A$, Poorly sorted, medium- to coarse-grained foraminifer-algal-crinoid-lump grainstone. A micritized, crushed Yukonella sp. is associated with numerous Endothyra of the group $E$. bowmani Phillips in Brown emend Brady. Univ. Montréal 277/35, section $71 \mathrm{~A}-4+250 \mathrm{ft} ; 685.8$ $\mathrm{m}$ above the base, Alapah Limestone, Zone 15, Ste. Genevieve age equivalent, middle late Viséan. $B$, Same facies as $A$, but with Koninckopora inflata (de Koninck) associated with Endothyranopsis compressus (Rauzer-Chernoussova and Reitlinger) and Planoendothyra sp. Univ. Montréal 277/34, section 71A-4+250 ft; $688.8 \mathrm{~m}$ above the base, Alapah Limestone, Zone 15, Ste. Genevieve age equivalent, middle late Viséan. $C$, Same facies as $A$, but with the enigmatic Paracalligelloides sp. associated with crushed Endothyra sp. and Priscella sp. Univ. Montréal 277/36, section 7 $1 A-4+250 \mathrm{ft} ; 688.8 \mathrm{~m}$ above the base, Alapah Limestone, Zone 15 , Ste. Genevieve age equivalent, middle late Viséan. $D, A$ heterocoral Hexaphyllia sp. in a slightly recrystallized calcispherid-rich wackestone (Calcisphaera sp., Vicinesphaera sp.). Univ. Montréal 278/2, section 71A-4+500 ft; $762 \mathrm{~m}$ above the base, Alapah Limestone, Zone 16i, lower Chester age equivalent, late Viséan. $E$ and $F$, A poorly sorted, slightly recrystallized foraminifer-crinoid-calcisphere-pellet packstone. Abundant Pseudoendothyra sp. are mixed with Calcisphaera laevis Williamson, Calcisphaera pachysphaerica (Pronina), Vicinesphaera sp., Parathurammina sp., Brunsia sp. and Priscella sp. Univ. Montréal $278 / 3$ and $278 / 5$, section $71 \mathrm{~A}-4+510 \mathrm{ft} ; 765.1 \mathrm{~m}$ above the base, Alapah Limestone, Zone $16 \mathrm{i}$, lower Chester age equivalent, late Viséan. G, A partially mud-filled thallus(?) of Asphaltina cordillerensis Mamet. Crinoid plates have extensive epitaxial overgrowth. Some pellets are present. Univ. Montréal 278/11, section $71 \mathrm{~A}-5+370 \mathrm{ft} ; 917.5 \mathrm{~m}$ above the base, Alapah Limestone, Zone $16 \mathrm{~s}$, lower Chester age equivalent, latest Viséan. $H$,Asteroarchaediscus of the group $A$. baschkiricus in a fine- to medium-grained well-sorted grainstone. Univ. Montréal 278/15, section 71A-5+280 $\mathrm{ft}$; $944.9 \mathrm{~m}$ above the base, Alapah Limestone, Zone 17, middle Chester age equivalent, early Namurian.
Endothyranopsis of the group E. crassus (Brady)

Eoendothyranopsis macrus (Zeller)

Eoendothyranopsis of the group E. ermakiensis (Lebedeva)

Eoendothyranopsis? robustus (McKay and Green)

Epistacheoides sp.

Globoendothyra of the group G. globulus d'Eichwald

"Irregularina" sp.

Kamaena sp.

Kamaena lahuseni (von Möller)

Koninckopora sp. Scarce

Koninckopora inflata (de Koninck) Very scarce

Paracalligelloides sp.

Parathurammina of the group P. cushmani Suleimanov

Parathurammina of the group $P$. suleimanovi Lipina

Planoendothyra sp.

Priscella sp.

Priscella prisca (Rauzer-Chernoussova and Reitlinger)

Pseudoammodiscus sp.

Pseudoissinella alaskaensis Mamet and Rudloff

Stacheoides sp.

Ungdarella sp.

Yukonella sp.

Yukonella bamberi Mamet and Rudloff

Vicinesphaera $\mathrm{sp.}$

Age: Zone 15, middle late Viséan, Ste. Genevieve age equivalent.

B-6 (2,320-2,520 ft); 707.1-768.1 m

Archaediscus sp.

Archaediscus of the group A. krestovnikovi RauzerChernoussova

Archaediscus krestovnikovi Rauzer-Chernoussova

Archaediscus koktjubensis Rauzer-Chernoussova

Archaediscus of the group A. moelleri Rauzer-Chernoussova

Brunsia sp.

Calcisphaera laevis Williamson

Calcisphaera pachysphaerica (Pronina)

Earlandia sp.

Endothyra sp.

Endothyra of the group E. bowmani Phillips in Brown emend Brady

Eostaffella sp.

Eotuberitina sp.

Epistacheoides sp.

Globoendothyra sp.

Neoarchaediscus sp., primitive

Parathurammina sp.

Priscella sp.

Pseudoammodiscus sp.

Pseudoendothyra sp.

Pseudoglomospira sp.

Tetrataxis sp.

Zellerina sp.

Zellerina discoidea (Girty)

Age: Zone 16i, late Viséan, lower Chester age equivalent.

B-7 $(2,700 \mathrm{ft}) ; 823 \mathrm{~m}$

Archaediscus sp.

Archaediscus of the group A. krestovnikovi RauzerChernoussova

Archaediscus krestovnikovi Rauzer-Chernoussova

Archaediscus koktjubensis Rauzer-Chernoussova

Calcisphaera sp.

Endothyra sp.

Eostaffella $\mathrm{sp.}$

Priscella sp.

Pseudoammodiscus sp. 
Pseudoendothyra sp.

Zellerina sp.

Zellerina discoidea (Girty)

Age: Zone 16i, late Viséan, lower Chester age equivalent.

B-8 $(2,760-3,000 \mathrm{ft}) ; 841.2-914.4 \mathrm{~m}$

Asphaltina cordillerensis Mamet and Rudloff

Archaediscus sp.

Archaediscus of the group A. krestovnikovi RauzerChernoussova

Archaediscus of the group A. moelleri Rauzer-Chernoussova Calcisphaera sp.

Diplosphaerina sp.

Earlandia sp.

Endothyra sp.

Neoarchaediscus sp.

Neoarchaediscus parvus (Rauzer-Chernoussova)

Neoarchaediscus regularis (Rauzer-Chernoussova)

Planospirodiscus $\mathrm{sp}$

Pseudoammodiscus sp.

Pseudoendothyra sp.

cf. Planoendothyra? sp.

Tetrataxis sp.

Zellerina sp.

Age: Zone 16s, latest Viséan, lower Chester age equivalent.

B-9 (3,070-3,140 ft); 935.7-957.1 m

Archaediscus sp.

Archaediscus of the group A. krestovnikovi RauzerChernoussova

Archaediscus krestovnikovi Rauzer-Chernoussova Asphaltina sp.

Asteroarchaediscus sp.

Asteroarchaediscus of the group A. baschkiricus (Krestovnikov and Teodorovitch)

Asteroarchaediscus gnomellus Brenckle

Calcisphaera sp.

Earlandia sp.

Endothyra of the group E. bowmani Phillips in Brown emend Brady

Endothyra cf. E. excellens (Zeller)

Neoarchaediscus sp.

Planospirodiscus sp.

Pseudoendothyra sp.

Pseudotaxis sp.

Stacheoides sp.

Tetrataxis sp.

Zellerina sp.

Age: Zone 17, earliest Namurian, middle Chester age equivalent.

B-10 (3,320-3,460 ft); 1,011.9-1,054.6 m

Archaediscus sp.

Archaediscus of the group A. krestovnikovi RauzerChernoussova

Archaediscus of the group A. moelleri Rauzer-Chernoussova Asphaltina sp.

Asphaltina cordillerensis Mamet

Asteroarchaediscus sp.

Asteroarchaediscus of the group A. baschkiricus (Krestovnikov and Teodorovitch)

Biseriella sp.

Biseriella parva (Chernysheva)

Calcisphaera laevis Williamson

Earlandia sp.

Endothyra sp.

Endothyra of the group E. bowmani Phillips in Brown emend Brady
Eostaffella sp.

Neoarchaediscus sp.

Neoarchaediscus incertus (Grozdilova and Lebedeva)

Planospirodiscus sp.

Planospirodiscus taimyricus Sossipatrova

Pseudoglomospira sp.

Zellerina sp.

Age: Zone 18, early Namurian, upper Chester age equivalent.

\section{BIOTA OF THE LAGOONAL FACIES, ALAPAH LIMESTONE, KONGAKUT RIVER SECTION}

The lower part of the Alapah Limestone in the Kongakut River section from 369 to $692 \mathrm{~m}$ suggests very shallow lagoonal sedimentation. The facies is strikingly similar to other Carboniferous carbonate lagoons of the Cordillera, for example, the Carnarvon Member, Mount Head Formation, Alberta (which has similar age, Zone 15) of the Tournaisian Shunda Formation in Alberta and British Columbia (Petryk and others, 1970). The biota is characterized by a great abundance of calcispheres; the genera Calcisphaera, Parathurammina, and Vicinesphaera are the most widespread. These calcispheres are usually observed as single, discrete spherules and show little trace of abrasion. The fragile parathuramminid spines are rather well preserved, particularly where they are coated by algal dust.

The nature of calcispheres is a controversial subject. It is, however, reasonable to assume that most of them are calcified cysts of algal spores. When they are in situ, they usually form clusters around poorly calcified thalli (see for instance Radiosphaera, pl. 10, fig. 14, in Mamet and Rudloff, 1972). This clustering habit was already noticed in the calcispheres of the Shunda Formation by Stanton (1963); it is rarely observed in the calcispheres of the Alapah Limestone. Calcispheres also occur in the form of a crown with octameral symmetry; a habit observed among Calcisphaera (Mamet, 1973). All these smooth calcispheres are finely perforated and have no aperture. They are, therefore, not foraminifers, or probable foraminifers?, as is suggested by most Russian authors (Suleimanov, 1945; Lipina, 1950; Reitlinger, 1957, 1960; Bogush and Yuferev, 1962, 1970; Pronina, 1963; Aizenberg and others, 1966; Brazhnikova and others, 1967, Menner and Reitlinger, 1971), an attribution accepted by Conil and Lys (1964), Loeblich and Tappan (1964), and Hallett (1970).

On the other hand, the nature of the spinose parathuramminid calcispheres remains debatable. Veevers (1970) published a unique photograph of a "cluster of united cells" from the Famennian Button Beds of Australia, he attributed them, with doubt, to sporangia of Uva Maslov. It is clear, however, that his figure 1, plate 31 , represents an in situ cluster of Vicinesphaera, which is closely similar to a cluster 
of Radiosphaera. Probably neither Calcisphaera nor Vicinesphaera should be considered foraminifers.

Since Vicinesphaera and Parathurammina are closely related, the latter genus might also be removed from the Protozoa. Up to now, no cluster of Parathurammina has been observed, and the "cells" are always disarticulated. This is true for the specimens from the entire Kongakut River section where the genus abounds. However, the distribution of the algal cyst Calcisphaera and the parathuramminids is strikingly similar. Eighty-six samples collected throughout the entire column of lagoonal sediments were analyzed for distribution of Vicinesphaera, Calcisphaera, Parathurammina, true foraminifers and Pseudoissinella, and Kamaena. The results of this analysis (fig. 12) show a very close relation between the distribution of smooth and spinose calcispheres, while no correspondence is observed with the other taxa. For more than $305 \mathrm{~m}$ of fine-grained pelletoidal carbonate rocks, the ratio of spinose calcispheres to smooth calcispheres is remarkably constant and varies from one-half to one- third. The ratio of Parathurammina to Vicinesphaera is also very constant. Such relations are also conspicuous in the Carnarvon Member of the Mount Head Formation in Alberta and in the Black Marbles of Dinant (VIa) in Belgium.

This close relationship may be the result of mechanical sorting. Indeed, spinose and smooth calcispheres have similar ranges of diameter and of wall thickness. Thus, this worldwide similar association is by no means proof that they have the same biological origin, and algal cysts could very well be mixed with monolocular foraminifers. Until in situ clusters of Parathurammina, similar to those of Radiosphaera or Vicinesphaera, are found, the question remains unanswered.

\section{REGIONAL CORRELATIONS}

\section{ENDICOTT GROUP}

The Kekiktuk Conglomerate is absent, owing either to nondeposition or to faulting at the base, from the bottom of section $69 \mathrm{~A}-1$, in the west end of the Sadlerochit Mountains (fig. 13). The Kekiktuk Conglomerate is absent owing to nondeposition from the eastern Sadlerochit Mountains section 68A-4A, 4B. At the Kongakut River section $71 \mathrm{~A}-3,4,5,6$, it is not exposed and is covered by tundra.

The Kekiktuk Conglomerate is well exposed at the base of section 71A-2 on the Clarence River. Here the Kekiktuk rests with angular unconformity on lower Paleozoic (Ordovician or Silurian) arenaceous limestone and is about $100 \mathrm{~m}$ thick. It consists of basal quartz-pebble conglomerate, black carbonaceous shales, nodular limestones and siltstones, and lightgray and brown, thin-bedded quartz sandstone and siltstones and is overlain by the dark-gray Kayak(?) Shale.

The section $70 \mathrm{~A}-7$ on the north flank of the large synclinorium east of the Aichilik River contains about $30 \mathrm{~m}$ of quartzite conglomerates, sandstones, and shales.

The Kekiktuk Conglomerate in section 70A-2, near the junction of Marsh Fork and the Canning River, is at least $61 \mathrm{~m}$ thick. It unconformably overlies the greenish-gray slates and phyllites of the Neruokpuk Formation. The lower $38 \mathrm{~m}$ of the Kekiktuk Conglomerate is medium- to massive-bedded pebble conglomerates and sandstones, with quartz and hematite cement. The upper $23 \mathrm{~m}$ consists of medium- to thin-bedded quartz sandstone, dark-gray siltstones, dark-gray shales, and thin coals. At the base of section 70A-4, near the Canning River, the Kekiktuk rests with angular unconformity on metamorphic rocks of the Neruokpuk Formation and is about $10 \mathrm{~m}$ thick. It consists of basal quartz-pebble conglomerate, black carbonaceous shales, and $5 \mathrm{~m}$ of strongly crossbedded light-gray quartz sandstone.

The Kayak(?) Shale is thin, about $15 \mathrm{~m}$ thick, in the western Sadlerochit Mountains. In section 69A-1 this brownish-gray calcareous unit rests unconformably on dolomites of Devonian age. The overlying basal beds of the Alapah Limestone are lower Chesterian in age, and the thin Kayak(?) Shale is probably lower Chesterian age. In section $70 \mathrm{~A}-4$, about $43.5 \mathrm{~km}$ to the south (fig. 13), the unit thickens markedly and is older; it contains microfossils of Meramecian, Zone 11, age. Approximately $372 \mathrm{~m}$ thick, the Kayak(?) is a sequence of dark-gray shales, thin-bedded argillaceous lime mudstones, dolomites, and thin-bedded dark-gray to black cherts. The upper 30 to $40 \mathrm{~m}$ of the unit becomes progressively more calcareous upward, and the contact with the Alapah Limestone is gradational.

The Kayak(?) Shale, $18 \mathrm{~km}$ to the southeast in section $70 \mathrm{~A}-2$, is only about $183 \mathrm{~m}$ thick. The predominant rock type is dark-gray shale, with only minor amounts of thin-bedded sandstones, siltstones, and yellow-weathering thin-bedded limestone. The base of the unit is gradational with the Kekiktuk Conglomerate, which contains abundant plant remains. The dark-gray shales of the Kayak(?) Shale change abruptly to the dark-gray bedded spiculitic cherts and dolomites of the Wachsmuth Limestone.

In the Clarence River section 71A-1 (figs. 3, 13) the Kayak(?) Shale contact with the Alapah Limestone is not exposed. The Kayak (?) Shale is about $75 \mathrm{~m}$ thick and is composed of dark-gray shales, nodular and lenticular interbeds of thin limestones, and brown to 


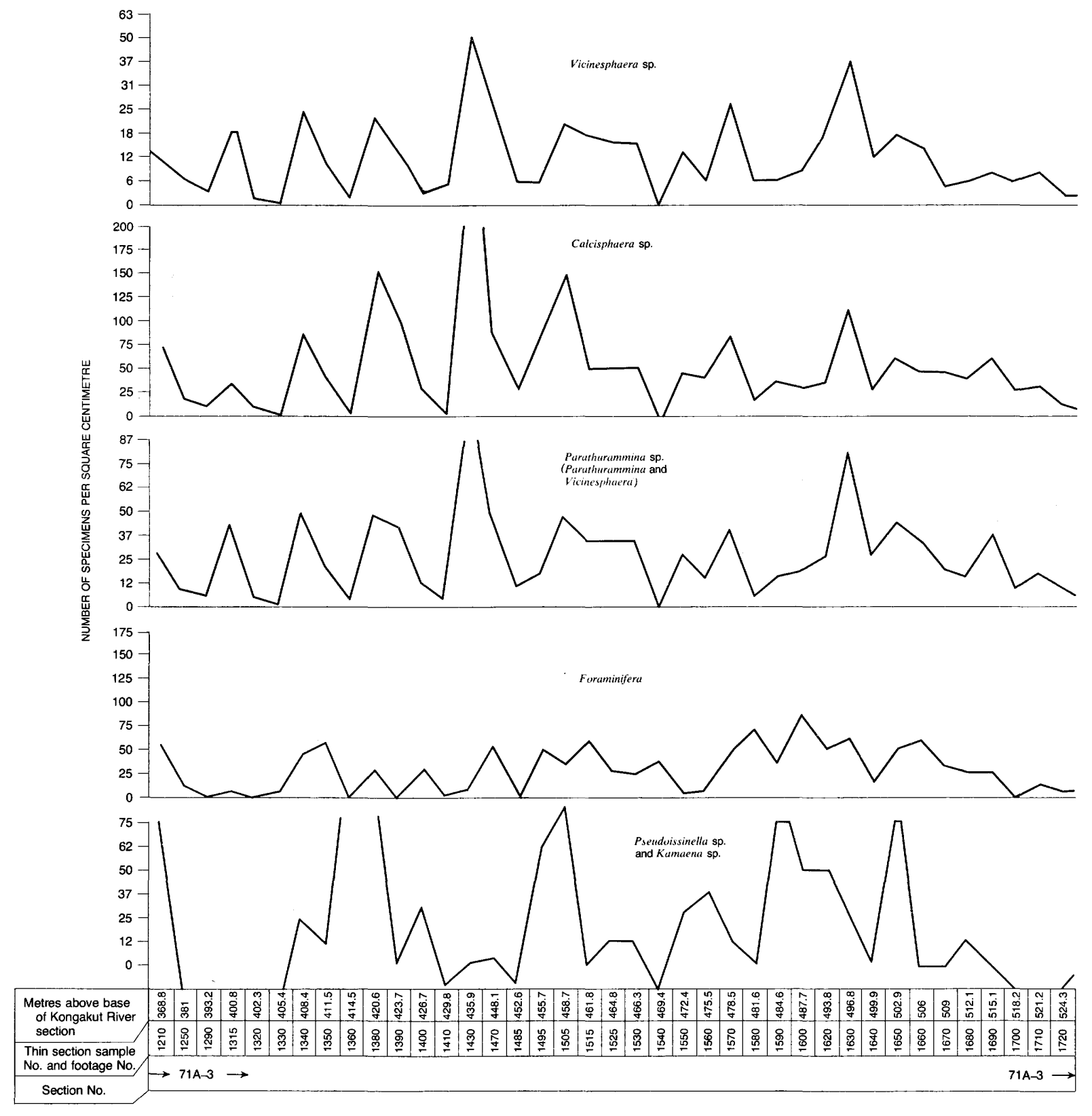

FIGURE 12.-Distribution of Vicinesphaera, Calcisphaera, Parathurammina, true foraminifers, Pseudoissinella, and Kamaena in the of smooth and spinose calcispheres; no correspondence is observed

pale-yellow-brown siltstones and sandstones. The Kayak(?) is not exposed at the Egaksrak River section 68A-5. It is absent at the east end of the Sadlerochit Mountains where thin beds of sandstone of the Itkilyariak Formation (Mull and Mangus, 1972; Armstrong and Mamet, 1974) rest directly on the Neruokpuk Formation. Pelletoid-ooid grainstones with microfossils of Zone 16s, Chesterian, age overlie these thin sandstone beds.

The composite section, 70A-6 and 70A-7, of the Kayak(?) Shale about $135 \mathrm{~km}$ east of section $70 \mathrm{~A}-2$ is about $442 \mathrm{~m}$ thick; the lower $137 \mathrm{~m}$ is dark-gray shale with a few thin lime mudstone beds and nodules. Above this segment is $92 \mathrm{~m}$ of highly siliceous, argillaceous, cherty, gray and dark-gray dolomites and limestones. The upper $213 \mathrm{~m}$ of the unit is calcareous dark-gray shale and thin-bedded argillaceous dark-gray coralliferous limestones. The contact with the basal Alapah Limestone is gradational.

The lower part of the Kayak(?) Shale is not exposed in the Kongakut River section (71A-3, 4, 5, 6; figs. 7, 13). The upper part is a dark-gray shale with thin siltstone interbeds followed by thin-bedded argillaceous and chert spiculitic lime mudstones and wackestones. The 

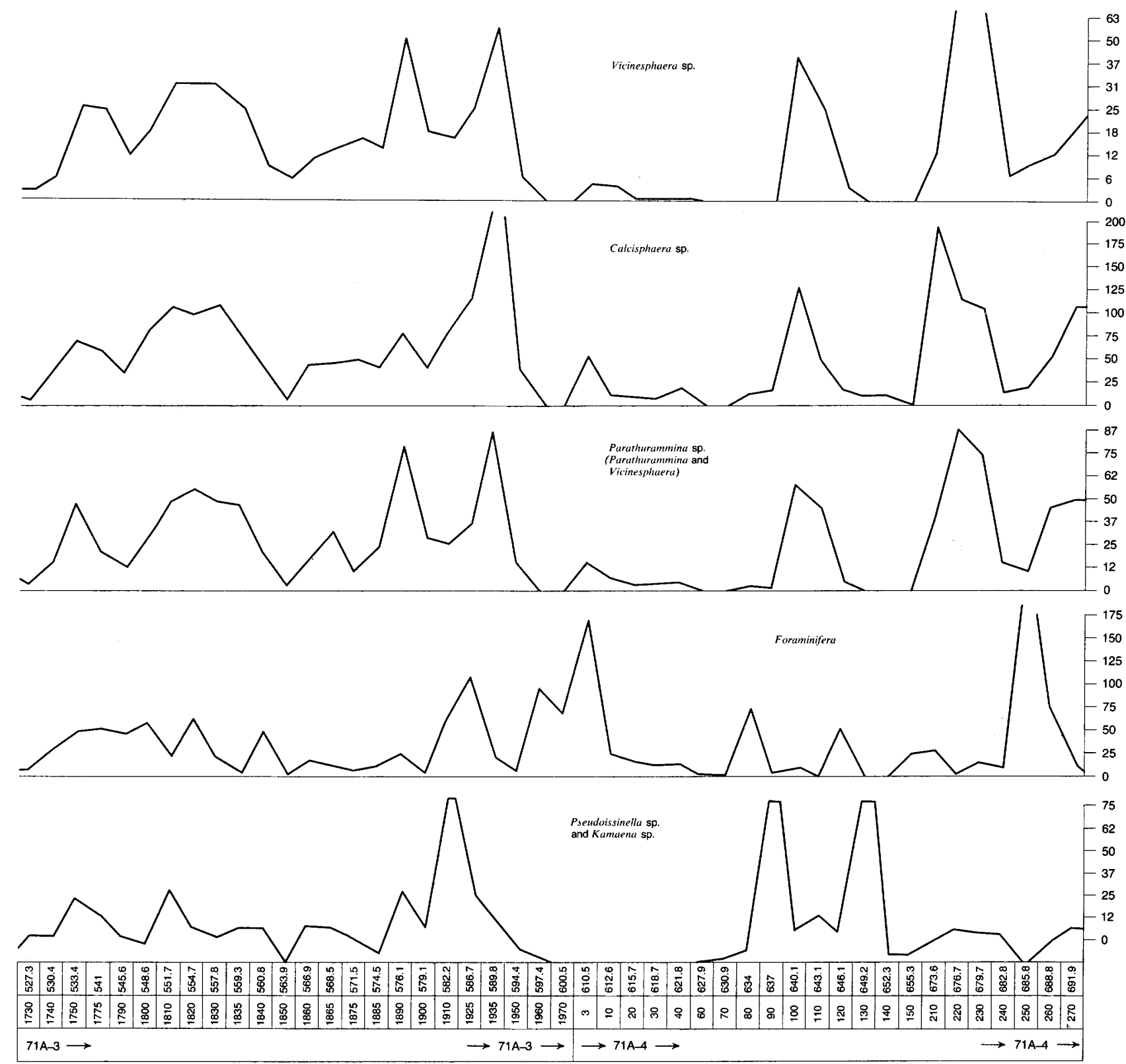

lagoonal facies of the Kongakut River section from 368.8 to $691.9 \mathrm{~m}$ above the base. Note the close relation between the distribution with other taxa. Eighty-six samples were studied in thin section.

beds in the middle part of the Kayak(?) Shale contain microfossils of Zone 12, and in the upper part of the Kayak(?) Shale of Zone 13/14, Meramecian, age.

\section{LISBURNE GROUP}

Because most of the carbonate rocks of this study are younger than Zone 12, the Wachsmuth carbonate facies is poorly represented. The interval from 244 to $450 \mathrm{~m}$ of section 70A-2 is considered to be a possible Wachsmuth equivalent. Likewise, the intervals from 140 to $220 \mathrm{~m}$ in the Kongakut River section, 130 to $400 \mathrm{~m}$ in section
$70 \mathrm{~A}-4$, and 160 to $220 \mathrm{~m}$ in section $70 \mathrm{~A}-6,7$ may represent Wachsmuth equivalents.

The base of the Lisburne Group is diachronous in the area of this study. In the southern series of east to west sections that run from the Kongakut River section $71 \mathrm{~A}-3,4,5,6$ west to Marsh Fork section $70 \mathrm{~A}-2,3$ and then north to the Plunge Creek section 70A-5, the contact between the Kayak(?) Shale and the Lisburne Group occurs in Zones 12 to 15 in Meramecian rocks. In the Sadlerochit Mountains $50 \mathrm{~km}$ to the north, the basal Alapah Limestone is in Zone $16_{\mathrm{i}}$ or $16_{\mathrm{s}}$, Chesterian. At Egaksrak River section $68 \mathrm{~A}-5,75 \mathrm{~km}$ to the east, 


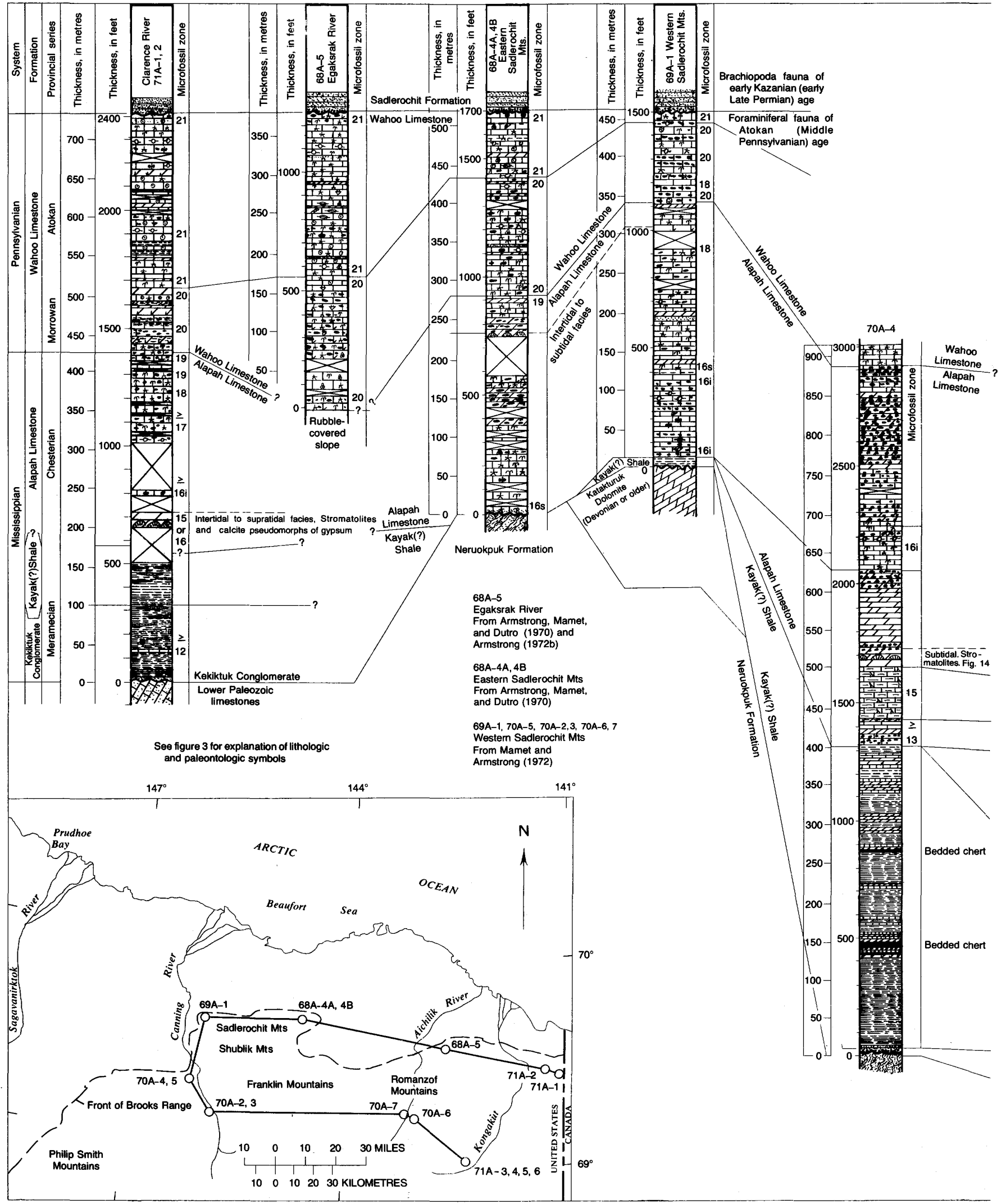

FIGURE 13.-Carboniferous biostratigraphic correlation 


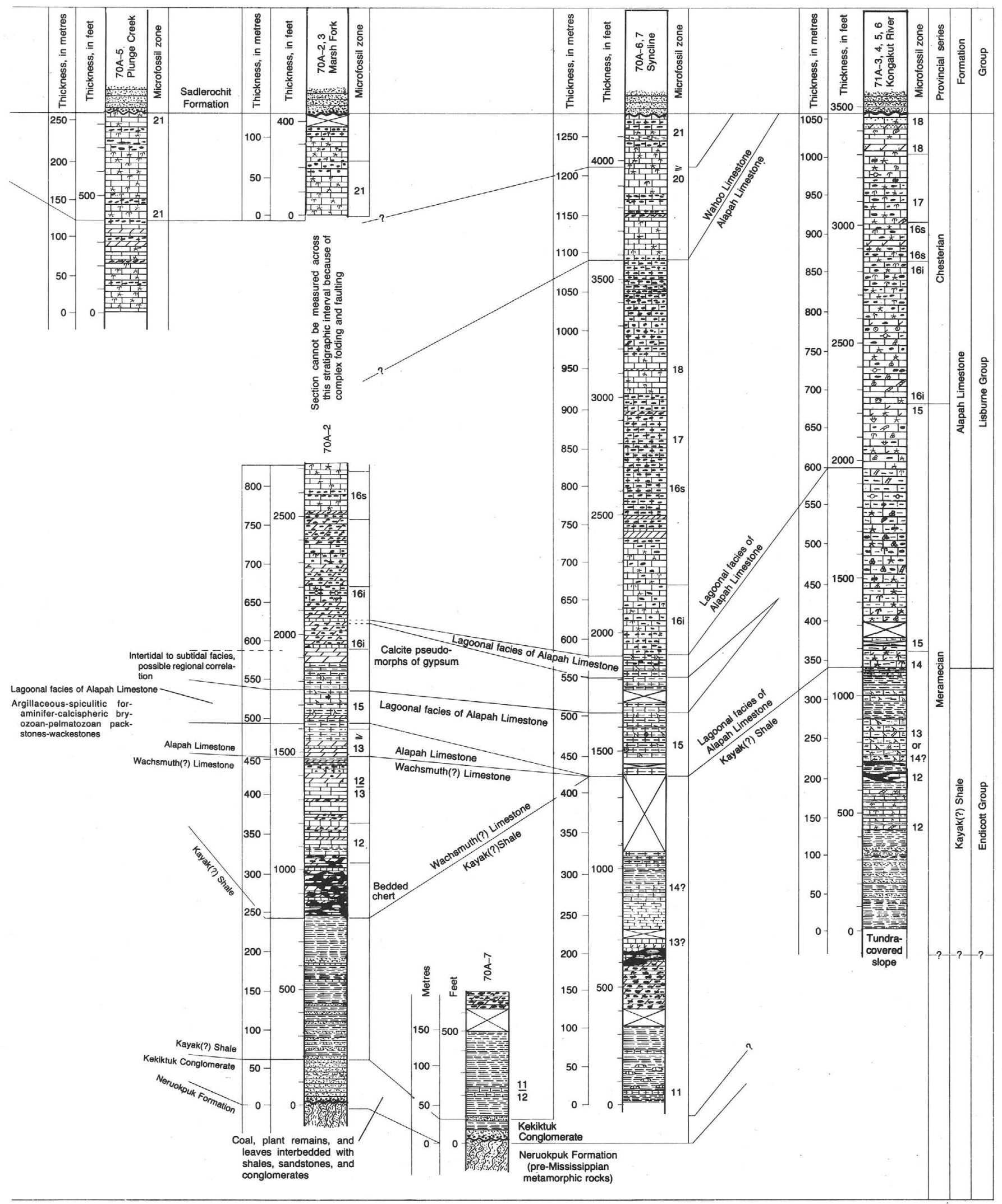

chart, northeastern Brooks Range, Alaska. 
neither the Alapah Limestone nor the Kayak(?) Shale is exposed. On the north flank of the Brooks Range adjacent to the Canadian border, $50 \mathrm{~km}$ to the east, where the contact of the Alapah Limestone with the Kayak(?) Shale is covered by talus, the contact is probably near the Meramecian-Chesterian boundary.

During Meramecian time, the sediments that now form the Sadlerochit Mountains stood as an island or positive area to the shale and shallow-water carbonate sediments being deposited east, west, and south of it.

By earliest Chester time, Alapah Limestone deposition extended over the whole region, including the Sadlerochit high, and the area northwestward to Prudhoe Bay (Armstrong and Mamet, 1974; Armstrong, 1974).

The Alapah Limestone varies in thickness, It is generally thinnest in the Sadlerochit Mountains-only $335 \mathrm{~m}$ thick on the west end and $278 \mathrm{~m}$ on the east end. Armstrong and Mamet (1974) report a thickness about $290 \mathrm{~m}$ in the subsurface at Prudhoe Bay (fig. 2). At the Clarence River section it is about $260 \mathrm{~m}$ thick. The sections to the south are thicker, at Plunge Creek section 70A-4, 5, the Alapah is at least $640 \mathrm{~m}$ thick and at the Syncline section $70 \mathrm{~A}-6$, about $670 \mathrm{~m}$ thick. At the Kongakut River section $71 \mathrm{~A}-3,4,5,6$, its original thickness is unknown (fig. 13) because it is cut by the pre-Permian erosion surface, but its remaining thickness is still about $457 \mathrm{~m}$. In general, the Alapah is relatively thick in the central part of the northeastern Brooks Range, thins towards the north flank of the range, and becomes younger at its base.

A highly characteristic rock type referred to as the lagoonal facies occurs in the southern series of sections in the lower part of the Alapah Limestone, Zone 15. It is a thin-bedded dark-gray argillaceous-spiculite-foraminiferal-calcisphere-bryozoan-pelmatozoan wackestone and packstone. It is about $70 \mathrm{~m}$ thick at the Plunge Creek section $70 \mathrm{~A}-4,5$ and extends eastward to the Kongakut River section 71A-3, 4, 5, 6 where it is $260 \mathrm{~m}$ thick. The beds at the Plunge Creek section $70 \mathrm{~A}-4,5$ are overlain by gray dolomites that contain well-developed stromatolites (fig. 14) and those at the Marsh Fork section by dolomites with abundant calcite pseudomorphs of gypsum. The basal beds of the Alapah Limestone at the Clarence River section 71A-1, 2 (figs. $3,13)$ are dolomites that have very well developed stromatolites, birdseye structures, lithoclasts, and abundant calcite pseudomorphs of gypsum. These beds were deposited in an intertidal to supratidal environment. The suggested correlation of these lower Chesterian carbonate regressive facies is shown in figure 13.

The Wahoo Limestone in the west end of the Sadlerochit Mountains is only about $122 \mathrm{~m}$ thick; at the east end of the Sadlerochit Mountains it is $241 \mathrm{~m}$ thick.

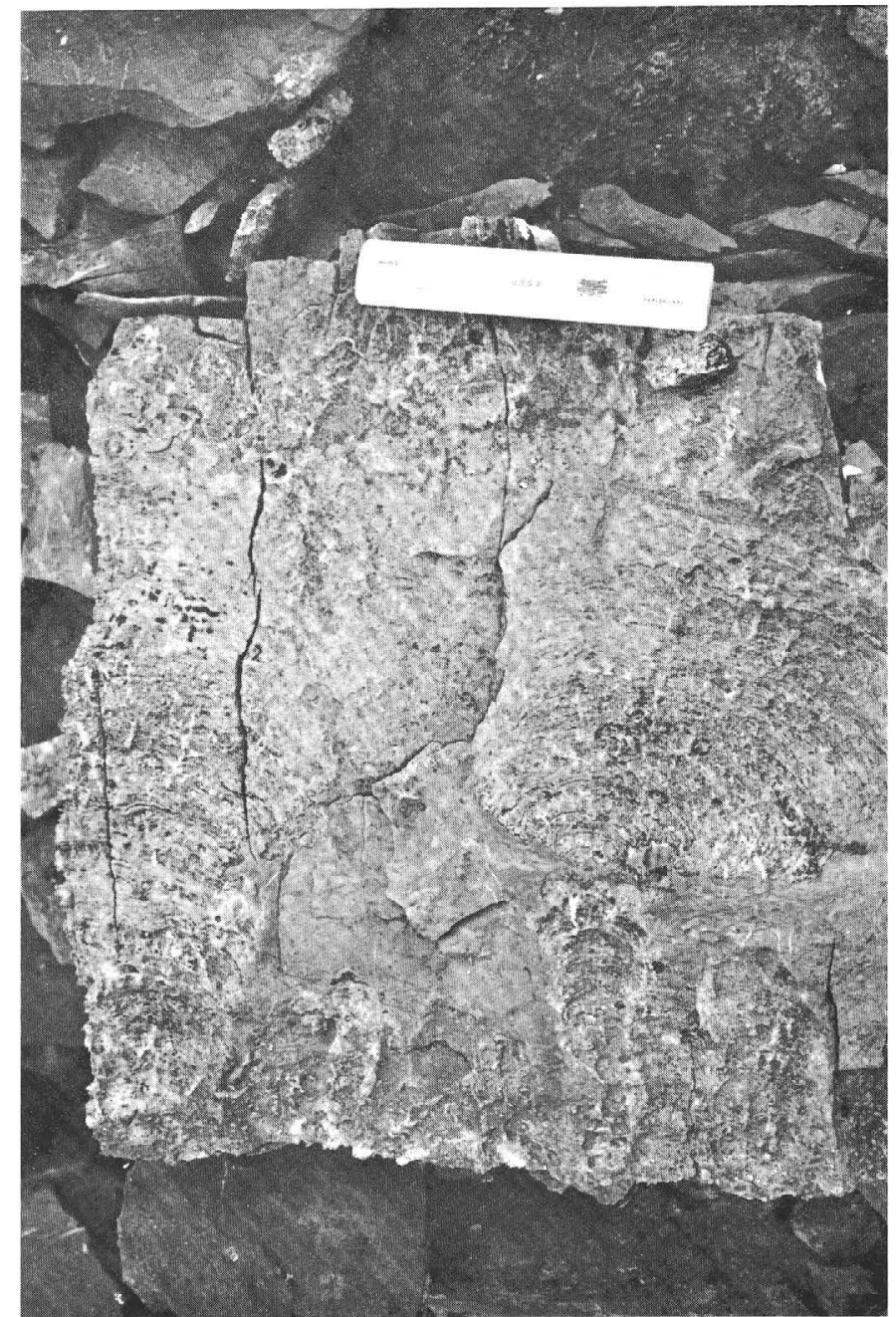

FigURE 14.-Well-developed and large stromatolites in the Alapah Limestone, $510 \mathrm{~m}$ above the base of the Plunge Creek section $70 \mathrm{~A}-4$. The scale is $15 \mathrm{~cm}$ long.

The eastward thickening of the Sadlerochit high is apparent at the Egaksrak River section $68 \mathrm{~A}-5$ where the Wahoo is $381 \mathrm{~m}$ thick, and adjacent to the Canadian border at the Clarence River section 71A-1, 2 where it is $314 \mathrm{~m}$ thick. The Wahoo Limestone on the north flank of the Brooks Range is primarily pelmatozoan-bryozoan wackestone, packstones and grainstones and ooid packstones and grainstones with minor amounts of pale-yellow-weathering dolomites and calcareous arenaceous shales.

The ooid facies is generally absent in the southern set of sections studied in the Franklin and Romanzof Mountains. Here the unit is from 183 to $275 \mathrm{~m}$ thick, and it consists of medium- to massive-bedded, gray to light-gray, slightly crossbedded pelmatozoan-bryozoan wackestone and packstones, and minor amounts of grainstone. Beds of thin dolomite and superficial ooid packstones are present sporadically. In the southern set 


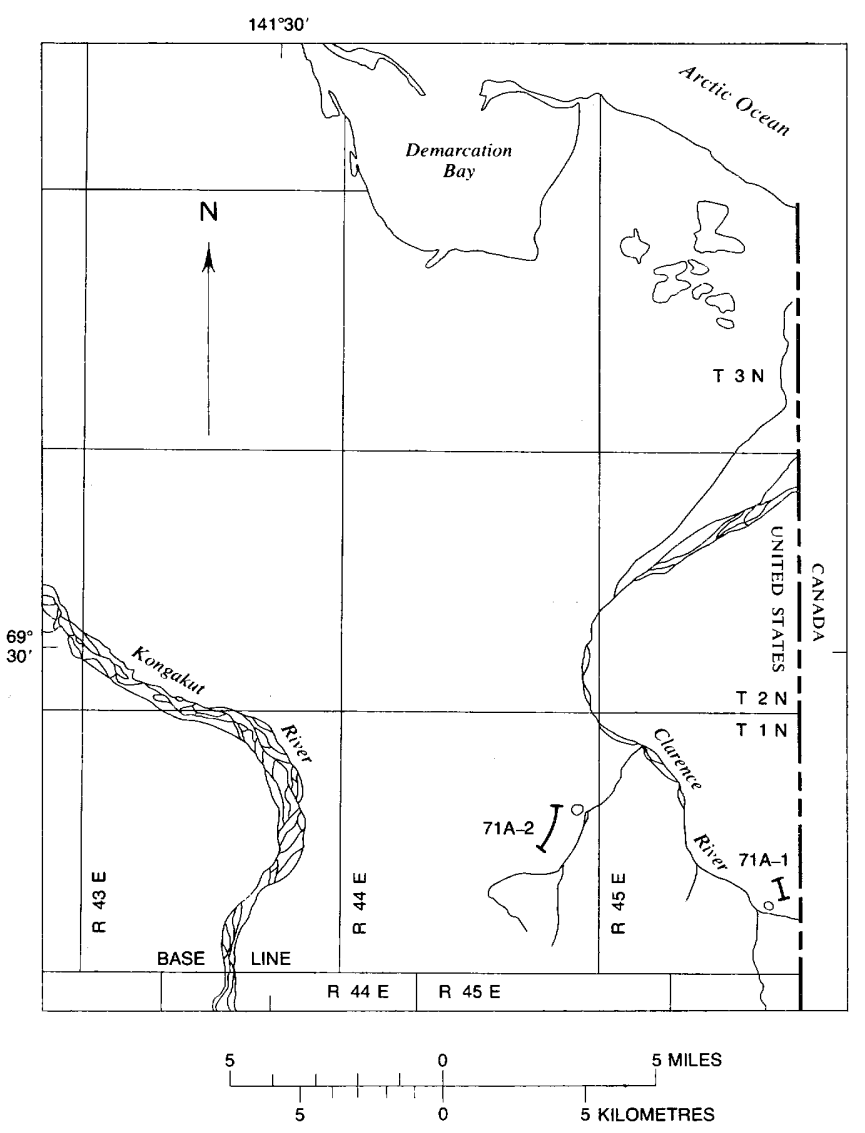

FIGURE 15-The Clarence River section $71 \mathrm{~A}-1,2$ in northeastern Brooks Range.

of sections, chert within the Wahoo is typically nodular and light gray to brown and generally occurs in the lime-mud-rich (micritic) beds. The contact between the Wahoo and Alapah Limestones is generally sharp, marked by the darker gray, thinner bedded lime mudstones and wackestones and packstones of the underlying Alapah Limestone.

The various horizons (fig. 13) containing stromatolites, birdseye structures, microdolomites, and calcite pseudomorphs of gypsum alternate with thick sequences of bryozoan-crinoid wackestones and ooid packstones and grainstones; the whole sequence was deposited in shallow water on a slowly subsiding platform. The intertidal to supratidal beds indicate that, at times, carbonate production on the platform exceeded rates of subsidence.

The Sadlerochit Formation of Permian and Triassic age unconformably overlies limestones of Atokan age, except at the Kongakut River section $71 \mathrm{~A}-3,4,5,6$, where it overlies the Upper Mississippian Alapah Limestone. Detterman (1970) reports that the basal Echooka Member of the Sadlerochit Formation contains a brachiopod fauna of early Kazanian, earliest Late Permian age. The unconformity between the Wahoo

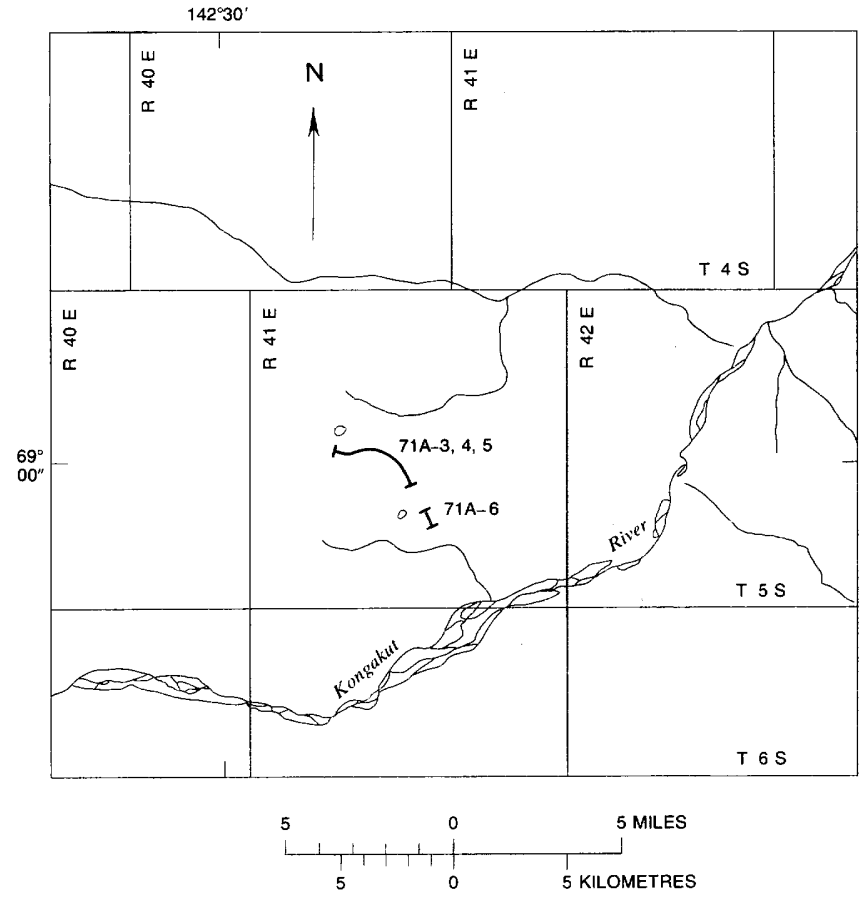

FIgURE 16.-The Kongakut River section $71 \mathrm{~A}-3,4,5,6$ in northeastern Brooks Range.

Limestone and Sadlerochit Formation represents a hiatus of Des Moinesian through Leonardian and possibly lower Guadalupian time. Where the Sadlerochit lies unconformably on the Alapah, the hiatus includes all of Pennsylvanian time and part of the uppermost Chesterian.

Armstrong, Mamet, and Dutro (1970) and Mamet and Armstrong (1972) illustrated the westward thinning of Atokan carbonate rocks in the Sadlerochit Mountains. Mamet and Armstrong (1972) and Armstrong (1972) reported that at many localities the highest few feet of Atokan carbonate rocks beneath the Sadlerochit Formation shows evidence of vadose weathering in the form of enlarged vertical joints and vugs filled with a clay similar to terra rossa. The basal beds of the Echooka Member of the Sadlerochit Formation are conglomerates or conglomeratic sandstone formed partly of rounded chert and limestone pebbles and cobbles derived from the underlying Wahoo Limestone.

Figures 15 and 16 are detailed graphic locations of the measured sections, Clarence River $(71 \mathrm{~A}-1,2)$ and Kongakut River (71A-3, 4, 5, 6).

\section{REFERENCES CITED}

Aizenberg, D. C., Brazhnikova, E. V., and Rostovceva, L. F., 1966, On the $\mathrm{C}_{\mathrm{I}} \mathrm{t}_{\mathrm{a}}$ Zone of the Donetz basin, in The fauna of the lowest part of the Tournaisian in the Donetz basin [in Russian]: Akad. Nauk Ukrain. SSR Inst. Geol. Nauk, p. 3-42, 18 pls. 
Armstrong, A. K., 1972, Pennsylvanian carbonates, paleoecology, and rugose colonial corals, eastern Brooks Range, arctic Alaska: U.S. Geol. Survey Prof. Paper 747, 19 p., 16 figs., 8 pls. [1973].

- 1974, Carboniferous carbonate depositional models, preliminary lithofacies and paleotectonic maps, arctic Alaska: Am. Assoc. Petroleum Geologists Bull., v. 58, no. 4, p. 646-660.

Armstrong, A. K., and Mamet, B. L., 1974, Carboniferous biostratigraphy, Prudhoe Bay State No. 1 to northeastern Brooks Range, arctic Alaska: Am. Assoc. Petroleum Geologists Bull., v. 58, no. 4, p. 621-645.

1975, Microfacies, microfossils and corals. Lisburne Group, arctic Alaska: U.S. Geol. Survey Prof. Paper 849.

Armstrong, A. K., Mamet, B. L., and Dutro, J. T., Jr., 1970, Foraminiferal zonation and carbonate facies of the Mississippian and Pennsylvanian Lisburne Group, central and eastern Brooks Range, Alaska: Am. Assoc. Petroleum Geologists Bull., v. 54, no. 5, p. 687-698, 4 figs.

-1971, Lisburne Group, Cape Lewis-Niak Creek, northwestern Alaska, in Geological Survey research 1971: U.S. Geol. Survey Prof. Paper 750-B, p. B23-B34, 9 figs.

Bogush, O. I., and Yuferev, O. V., 1962, Foraminifera and stratigraphy of the Carboniferous deposits in Kara-Tau and Talaskiy Ala-Tau [in Russian]: Akad. Nauk SSSR Sibirsk. Otdeleniye Inst. Geologii i Geofiziki, p. 1-234, 9 pls.

-1970, Foraminiferida, in The Carboniferous of the Omolon and southwestern Kolyma Massif [in Russian]: Akad. Nauk SSSR Sibirsk. Otdeleniye Inst. Geologii i Geofiziki, Bull. 60. p. 68-74.

Bowsher, A. L., and Dutro, J. T., Jr., 1957, The Paleozoic section in the Shainin Lake area, central Brooks Range, Alaska: U.S. Geol. Survey Prof. Paper 303-A, 39 p., 6 pls., 4 figs.

Brazhnikova, N. E., Vakartchuk, G. I., Vdovenko, M. V., Viniitchenko, L. V., Karpova, M. A., Kolomietz, Ia. I., Potievskaia, P. D., Rostovceva, L. P., and Chevtchenko, G. D., 1967, Marker micro-faunistic horizons of the Carboniferous and the Permian of the Dniepr-Donetz basin [in Russian]: Izdat. "Naukova Dumka," Kiev, p. 1-224, 59 pls.

Brosgé, W. P., Dutro, J. T. Jr., Mangus, M. D., and Reiser, N. H., 1962, Paleozoic sequence in eastern Brooks Range, Alaska: Am. Assoc. Petroleum Geologists Bull., v. 46, no. 12, p. 2174-2198.

Conil, R., and Lys, M., 1964, Matériaux pour l'étude micropaléontologique du Dinantien de la Belgique et de la France (Avesnois). Pt. I, Algues et Foraminiferes; Pt. 2, Foraminifêres: Louvain Univ. Inst. Geol. Mem., v. 23, 335 p., 42 pls.

Detterman, R. L., 1970, Sedimentary history of the Sadlerochit and Shublik Formations in northeastern Alaska, in Adkison, W. L., and Brosgé, M. M., eds., Proceedings of the geological seminar on the North Slope of Alaska: Am. Assoc. Petroleum Geologists, Pacific Sec., Los Angeles, p. O-1-O-13, 9 figs.

Dunham, R. J., 1962, Classification of carbonate rocks according to deposition texture, in Classification of carbonate rocks-A symposium: Am. Assoc. Petroleum Geologists Mem. 1, p. 108-121.

Dutro, J. T., Jr., Brosgé, W. P., and Reiser, H. N., 1972, Significance of recently discovered Cambrian fossils and reinterpretation of Neruokpuk Formation, northeastern Alaska: Am. Assoc. Petroleum Geologists Bull., v. 56, no. 4, p. 808-812.

Hallett, D., 1970, Foraminifera and algae from the Yoredale "Series" (Viséan-Namurian) of northern England: Congrès Avanc. Strat. Carbonifère, 6ème, Sheffield, 1967, Compte Rendu, p. 873-885.

Lipina, O. A., 1950, Foraminifera from the Upper Devonian of the Russian platform [in Russian]: Akad. Nauk SSSR Geol. Inst. Trudy 119 , no. 4 , p. $110-132,3$ pls.

Loeblich, A. R., Jr., and Tappan, H., 1964, Protista, Pt. C, in Moore, R. C., ed., Treatise on invertebrate paleontology: Geol. Soc. America and Kansas Univ. Press, p. 1-900.
Macqueen, R. W., Bamber, E. W., and Mamet, B. L., 1972, Lower Carboniferous stratigraphy and sedimentology of the southern Canadian Rocky Mountains: Internat. Geol. Cong., 24th, Guidebook, Excursion C-17, p. 1-62.

Mamet, B. L., 1962, Remarques sur la microfauna de Foraminiferes du Dinantien: Soc. Géol. Belgique, v. 70, no. 2, p. 166-173. 1968, Foraminifera, Etherington Formation (Carboniferous), Alberta, Canada: Canadian Assoc. Petroleum Geology Bull., v. 16 , no. 2, p. 167-179.

1973, Microfaciès viséens du Boulonnais (Nord): Rev. Micropaléontologie, v. 16 , no. 2, p. 101-124, 5 pls.

Mamet, B. L., and Armstrong, A. K., 1972, Lisburne Group, Franklin and Romanzof Mountains, northeastern Alaska, in Geological Survey research 1972: U.S. Geol. Survey Prof. Paper 800-C, p. C127-C144, 10 figs.

Mamet, B. L., and Belford, D., 1968, Carboniferous Foraminifera, Bonaparte Gulf basin, northwestern Australia: Micropaleontology, v. 14 , no. 3 , p. $339-347$.

Mamet, B. L., and Gabrielse, H., 1969, Foraminiferal zonation and stratigraphy of the type section of the Nizi Formation (Carboniferous systems, Chesterian Stage), British Columbia: Canada Geol. Survey Paper 69-16, p. 1-21, 6 figs.

Mamet, B. L., and Mason, D., 1968, Foraminiferal zonation of the lower Carboniferous Connor Lake section, British Columbia: Canadian Assoc. Petroleum Geologists Bull., v. 16, no. 2, p. 147-166.

Mamet, B. L., and Rudloff, B., 1972, Algues carbonifères de la partie septentrionale de l'Amérique du Nord: Rev. Micropaléontologie, v. 15 , no. 2 , p. $75-114,10$ pls.

Mamet, B. L., and Skipp, B. A., 1970, Preliminary foraminiferal correlations of early Carboniferous strata in the North American Cordillera, in Colloque sur la stratigraphie du Carbonifêre: Liège Univ. Cong. et Colloques, v. 55, p. 327-348.

Menner, V. V., and Reitlinger, E. A., 1971, Foraminiferal provincialism during the Middle and Upper Devonian in the Siberian platform [in Russian]: Akad. Nauk SSSR Voprosy Mikropaleontologii, v. 14 , p. 25-34.

Mull, C. G., and Mangus, M. D., 1972, Itkilyariak Formation: New Mississippian Formation of Endicott Group, Arctic Slope of Alaska: Am. Assoc. Petroleum Geologists Bull., v. 56, no. 8, p. 1364-1369, 6 figs.

Petryk, A. A., Mamet, B. L., and Macqueen, R. W., 1970, Preliminary foraminiferal zonation, Rundle Group and uppermost Banff Formation (Lower Carboniferous), southwestern Alberta: Canadian Assoc. Petroleum Geology Bull., v. 18, no. 1, p. 84-103.

Pronina, T. V., 1963, Carboniferous foraminifers of the Berezovo Series in the eastern slope of the southern Ural Mountains, in Papers on the problems of stratigraphy, no. 7, Stratigraphy and fauna of the Paleozoic of the Ural Mountains [in Russian]: Akad. Nauk SSSR Ural. Fil., Geol. Inst. Trudy 65, p. 119-176, 7 pls.

Reiser, H. N., Dutro, J. T., Jr., Brosgé, W. P., Armstrong, A. K., and Detterman, R. L., 1970, Progress map, geology of the Sadlerochit and Shublik Mountains [Alaska]: U.S. Geol. Survey open-file map, scale 1:63,360.

Reitlinger, E. A., 1957, Devonian spheres of the Russian platform [in Russian]: Akad. Nauk SSSR Doklady, v. 115, no. 4, p. 773-776. 1960, Characteristic microscopical organic remains of the Ozerko-Khovansk Formation: Akad. Nauk SSSR, Geol. Inst. Trudy, Bull. 14, p. 135-179, 3 pls.

Sando, W. J., Mamet, B. L., and Dutro, J. T., Jr., 1969, Carboniferous megafaunal and microfaunal zonation in the northern Cordillera of the United States: U.S.Geol. Survey Prof. Paper 613-E, 29 p., 7 figs.

Stanton, R. J., 1963, Upper Devonian calcispheres from the Redwater and South Sturgeon Lake reefs, Alberta, Canada: Canadian 
Assoc. Petroleum Geology Bull., v. 11, no. 4, p. 410-418.

Suleimanov, I. S., 1945, Some new species of small Foraminifera from the Tournaisian of the Ishimbaevo oil-bearing region [in Russian]: Akad. Nauk SSSR Doklady, v. 48, no. 2, p. 124-127.

Veevers. J. J.. 1970. Upper Devonian and Lower Carboniferous calcareous algae from the Bonaparte Gulf basin, northwestern
Australia: Australia Bur. Mineral Resources, Geology and Geophysics Bull. 116, p. 174-188, 22 pls.

Wood, G. V., and Armstrong, A. K., 1975, Diagenesis and stratigraphy of the Lisburne Group limestones of the Sadlerochit Mountains and adjacent areas, northeastern Alaska, U.S. Geol. Survey Prof. Paper 857, 47 p. 



\section{INDEX}

[Italic page numbers indicate both major references and descriptions]

A

Page

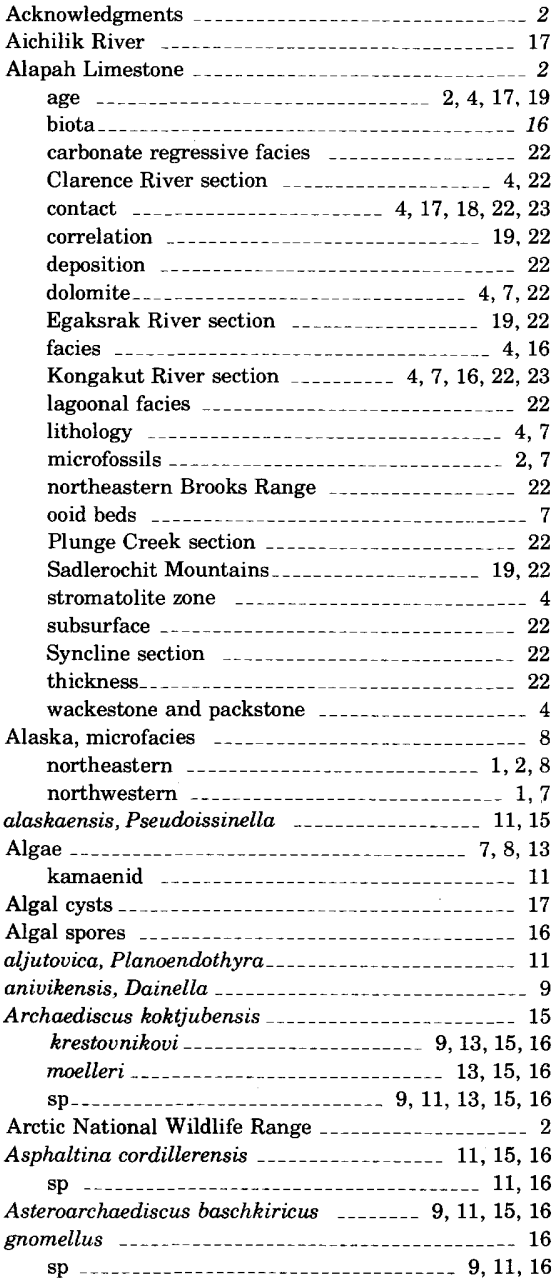

$\mathrm{sp}$

, 11, 16

baileyi, Globoendothyra

9,13

bamberi, Yukonella

15

Banffela sp _......... 13 baschkiricus, Asteroarchaediscus -_-_-_ 9, 11, 15, 16 Biostratigraphy -..-_..-..- 7 Biota, lagoonal facies Biseriella parva -_...... 11, 16

sp

Black Marbles, Dinant, Belgium

bowmani, Endothyra Brachiopod Brachiopod fauna

britishensis, Pseudoendothyra _............... 11 Brooks Range

$1,2,7,22$

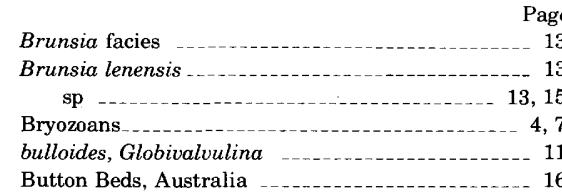

C

Calcisphaer

16,17 distribution 17

laevis -.-. $9,13,15,16$ pachysphaerica _._._._._._._._. $9,11,13$ sp_____ 9, 11, 13, 15, 16

Calcispheres_.......... 11, 13, 16 Alapah Limestone _._._. 16 Shunda Formation Canning River _._.

Carbonate rock classification

Carbonate rocks, Sadlerochit Mountains _._-_._-_ 23

Carboniferous microfossils -.................- 1

Carboniferous rocks, northern Cordillera, United States western Canada

Carboniferous zonations, Cordilleran Eurasian _.................. 8 Carnarvon Member, Mount Head Formation, Alber-

ta

Clarence River Clarence River section

Alapah Limestone _................... 4, 17, 22 correlation -
graphic location Kayak(?) Shale _._....._._. 4, 17

Kekiktuk Conglomerate -._-_-_._-_._-_ 17 microfossil list _........... 8, 14 Wahoo Limestone _._._. clavatula, Earlandia Climacammina sp _._._........... 11 Coal beds ........ 4 compressus, Endothyranopsis _...............13, 15 Corals, colonial Cordillera - .

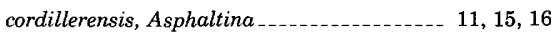
Correlations, regional _._._..._................ 17 crassus, Endothyranopsis _._-_._-_._-_._- 15

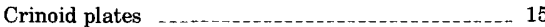
Crinoids_cushmani, Parathurammina --.---_-_-_----- 13, 15

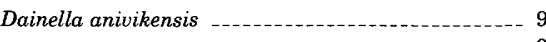

Detterman, R. L., cited

devexa, Priscello

Dinant, Black Marbles, Belgium _-_._. 17

Diplosphaerina sp

discoidea, Zellerina _._....................... 15, 16

Dolomites, Clarence River section -_-_-_-_-_-_-- 22

Devonian - -

Marsh Fork section

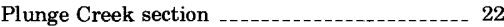

Dunham, R. J., cited
E

Page

Earlandia clavatula vulgaris _._. $9,11,13,15$ sp___._._._._._._._._. $9,11,13,15,16$ Earlandinella sp _.................. 11,

Echinoderms

Echinoid spines

Echooka Member, Sadlerochit Formation .....-_.- 23

Egaksrak River section, Alapah Limestone .... 19, 22 Kayak(?) Shale _-_._._._...... 18, 19, 22 microfossil list Wahoo Limestone

Endicott Group regional correlations -

Endicott Mountains -......... 2

Endothyra bowmani _..._._._._._. 9, 13, 15, 16 excellens _........................................ 16 similis ...... 9, 13, 15 sp

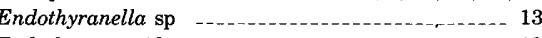

Endothyranopsids _............... 13

Endothyranopsis compressus - 13,15 crassus._-_-_-_. 15 sp -

Endothyrids -.............. 13

Eoendothyranopsis ermakiensis _._......... 11, 13, 15 macrus _-____- 13, 15 pressus robustus_._._._._. scitulus _........... 13 spiroides _-_-_-

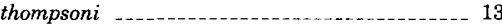
utahensis sp Eoforschia sp -

Eoschubertella yukonensis _._.________._. 7, 11 sp -_..._._. Eostaffella sp Eotuberitina $\mathrm{sp}$-_............... 13, 15 Epistacheoides sp _._._........... 13, 15 ermakiensis, Eoendothyranopsis_._._._._._. 11, 13, 15 excellens, Endothyra

\section{F, G, H, I}

Foraminifera assemblages

Fossils, plants

Franklin Mountains -

Globivalvulina bulloides

sp -

Globoendothyra baileyi _........... 9, 13

globulus

paula -_._.

tomiliensis _.t-

sp -

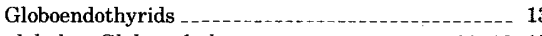

globulus, Globoendothyra

gnomellus, Asteroarchaediscus ....-.-.-_-_........ 16

Gypsum -.......... 4, 22, 23

Heterocoral -

Hexaphyllia sp -.......-_- 15

incertus, Neoarchaediscus _............... 7, 11, 16

index, Kamaena 


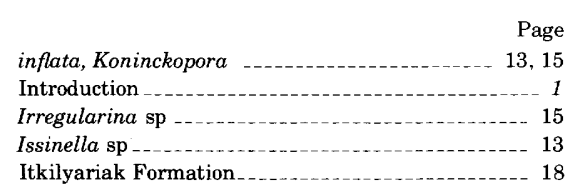

$\mathrm{K}$

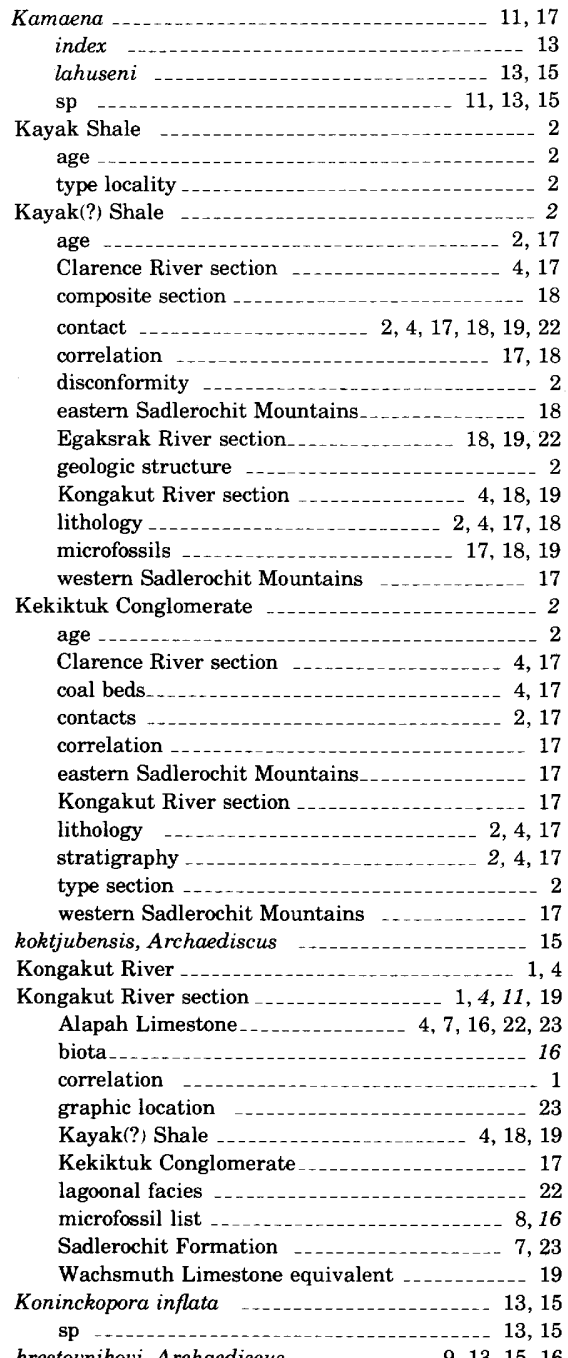

krestounikovi, Archaediscus $9,13,15,16$

L

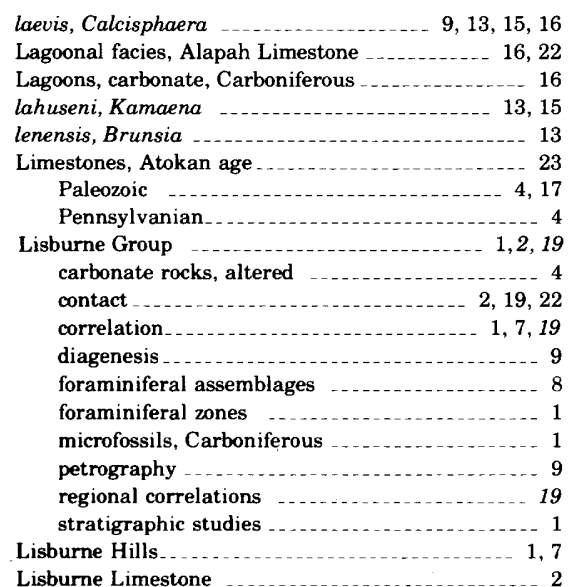

| $\quad$ Page

macrus, Eoendothyranopsis _..._._. 13, 15

Marsh Fork 1,17

Marsh Fork section, Kayak(?) Shale microfossil list _._._-_._._._._. 8

Microfaunal assemblage zones _..._. 7

Microfacies, Alaska _._.

Microfossil list

Clarence River section

eastern Sadlerochit Mountains section

Egaksrak River section

Kongakut River section

Marsh Fork section

Plunge Creek section

Syncline section _...... 8

western Sadlerochit Mountains section _-_._-_ 8

Microfossils, Alapah Limestone

Carboniferous .........- 1

Franklin Mountains

Kayak(?) Shale

Lisburne Group _...

Romanzof Mountains

Wachsmuth Limestone .................. 2

Wahoo Limestone

Millerella sp -_-_-_-_-_- 11

minimus, Planospirodiscus _-_-_-_._-_._- 11

moelleri, Archaediscus -

Mount Head Formation, Carnarvon Member, Alberta

Mount Wachsmuth. 2

\section{$\mathrm{N}, \mathrm{O}$}

Neoarchaediscus incertus -_-_-_-_-_-_-_-- 7,11, 16

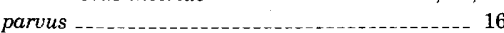
regularis _._-___-_ 16

sp _._. 9, 11, 15, 16 Neruokpuk Formation Neruokpuk Lakes _.....-- 2

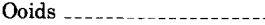

Ostracodes _.... 13

\section{$P$}

pachysphaerica, Calcisphaera _____. 9, 11, 13, 15 Palaeocancellus sp

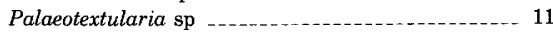
Paracalligelloides sp
Parathurammina

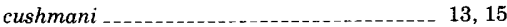

Kongakut River section

suleimanovi

sp _-_ 11, 13, 15

Parathuramminids, distribution _..._._._._._. 17

parva, Biseriella

parvus, Neoarchaediscus -_-_.- 16

regularis, Neoarchaediscus _................ 16

paula, Globoendothyra _-_..._... 13

Pelecypods _-

Pellets _._._. 13, 15

Pelmatozoan plates

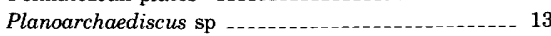

Planoendothyra aljutovica sp _....._. $11,13,15,16$

Planospirodiscus minimus taimyricus _._. sp _. 9, 11, 16

Plunge Creek section, Alapah Limestone -..._-_._- 22 Kayak(?) Shale _._._. 19 lagoonal facies . microfossil list ......... 8 pressus, Eoendothyranopsis _............... 13

prisca, Priscella

Priscella devexa prisca _........ 9, 13, 15 sp _...... 9, 13, 15 Protozoa -................. 17

Prudhoe Bay -

Pseudoammodiscus sp
Page

Pseudocornuspira sp _..._. 11

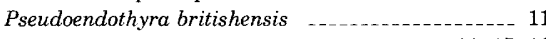
sp _....._-_. 11, 15, 16

Pseudoglomospira sp

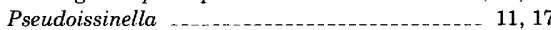
alaskaensis _._. sp _______ 13,15

Pseudostaffella $\mathrm{sp}$-_._._._. 7,

Pseudotaxis sp

\section{Q, R}

Quasiarchaediscus rugosus __________ 11 sp Radiolarite -....... 7

Radiosphaera _. 16, 17

Radiosphaerina sp _-_._-_._- 15

regularis, Neoarchaediscus parvus

robustus, Eoendothyranopsis _____._._._. 11, 13, 15

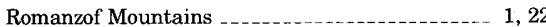

rugosus, Quasiarchaediscus ........... 11

\section{S}

Sadlerochit Formation $\quad 4,7,23$

Clarence River section

contact

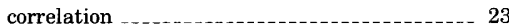

Echooka Member -.... 23

Kongakut River section ......... 7, 23

Sadlerochit high

Sadlerochit Mountains _._._... 1, 17, 22

carbonate rocks

eastern section, diagenesis _._- 9 microfossil list petrography _........- 9

Meramecian time

western section, diagenesis --_-_-_-_-_-_- 9 microfossil list_..........-- 8 petrography _.......... 9

scitulus, Eoendothyranopsis _._._. 13

Shainin Lake -

Shainin Lake area -.......... 2

Shale, black

Shunda Formation, Alberta -

British Columbia

similis, Endothyra _-_._._. 9, 13, 15

skimoensis, Stacheia _...__-_ 7, 9, 13

Skippella $\mathrm{sp}_{\text {-_...-. }}$

spiroides, Eoendothyranopsis _._. 9

Stacheeinae - ........ 11

Stacheia skimoensis sp Stacheoides sp -

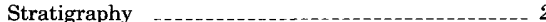

Stromatolites _._._._._._._._._._._._._... 4, 22, 23

suleimanovi, Parathurammina -.... 13, 15

Syncline section, Alapah Limestone -_-.--_-_--- 22

microfossil list _............-_. 8

Synclinorium, Aichilik River

T, U, V

Taimyr-Alaska foraminifera

taimyricus, Planospirodiscus _-_._. 11, 16

Terra rossa_._...

Tetrataxis sp -

thompsoni, Eoendothyranopsis _._._-_._- 13

tomiliensis, Globoendothyra

Tuberitina sp....- 11

Ungdarella

sp _.

utahensis, Eoendothyranopsis _._._............. 13

Uva _................ 16

Vadose weathering, carbonate rocks -_-_ 23

Veevers, J. J., cited -._. 16

Vicinesphaera

sp

vulgaris, Earlandia 


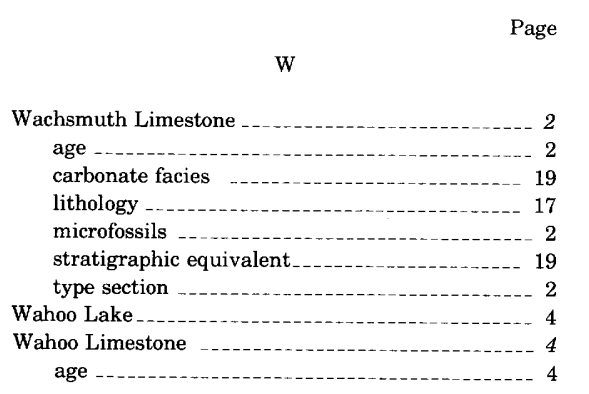

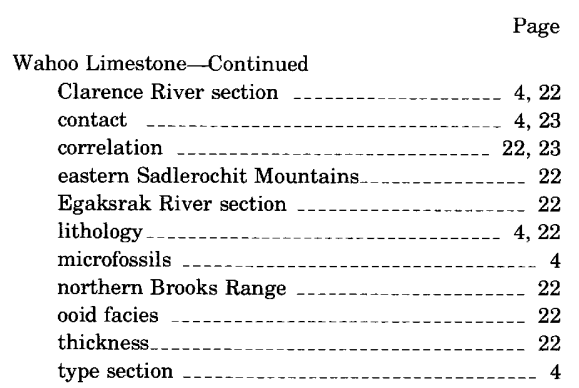

Page

Wahoo Limestone-Continued western Sadlerochit Mountains _._._._..... 22

Whistler Creek -

$\mathrm{Y}, \mathrm{Z}$

Yukonella bamberi sp -

yukonensis, Eoschubertella _................ 7,11

Zellerina discoidea

sp




